NBER WORKING PAPER SERIES

\title{
THE EMPLOYMENT EFFECTS OF STATE HIRING CREDITS DURING AND AFTER THE GREAT RECESSION
}

\author{
David Neumark \\ Diego Grijalva \\ Working Paper 18928 \\ http://www.nber.org/papers/w18928 \\ NATIONAL BUREAU OF ECONOMIC RESEARCH \\ 1050 Massachusetts Avenue \\ Cambridge, MA 02138 \\ March 2013
}

We are grateful to Patrick Button for outstanding research assistance. We are also grateful to the Annie E. Casey Foundation for research support. All views expressed are our own, and are not those of the Foundation. We thank Daniel Wilson for providing data on federal stimulus spending based on the Recovery.gov website, Henry Farber and Robert Valletta for providing data on Unemployment Insurance benefit extensions, Carl Klarner for providing data on state political control, and Wyatt Clarke, Graeme Boushey, Garth Brazleton, and Adriana Kugler and anonymous referees for helpful comments. All views expressed are our own, and are not those of the Foundation. We thank Daniel Wilson for providing data on federal stimulus spending based on the Recovery.gov website, and Henry Farber and Robert Valletta for providing data on Unemployment Insurance benefit extensions. The views expressed herein are those of the authors and do not necessarily reflect the views of the National Bureau of Economic Research.

NBER working papers are circulated for discussion and comment purposes. They have not been peerreviewed or been subject to the review by the NBER Board of Directors that accompanies official NBER publications.

(C) 2013 by David Neumark and Diego Grijalva. All rights reserved. Short sections of text, not to exceed two paragraphs, may be quoted without explicit permission provided that full credit, including $(\subset$ notice, is given to the source. 
The Employment Effects of State Hiring Credits During and After the Great Recession David Neumark and Diego Grijalva

NBER Working Paper No. 18928

March 2013, Revised June 2015

JEL No. J23,J38

\begin{abstract}
$\underline{\text { ABSTRACT }}$
State and federal policymakers grappling with the aftermath of the Great Recession sought ways to spur job creation, in many cases adopting hiring credits to encourage employers to create new jobs. However, there is virtually no evidence on the effects of these kinds of counter-recessionary hiring credits - the only evidence coming from much earlier studies of the federal New Jobs Tax Credit in the 1970s. This paper provides evidence on the effects of state hiring credits on job growth. For many of the types of hiring credits we examine we do not find positive effects on job growth. However, some specific types of hiring credits - most notably including those targeting the unemployed, those that allow states to recapture credits when job creation goals are not met, and refundable hiring credits - appear to have succeeded in boosting job growth, more so during the Great Recession period or perhaps recessions generally. At the same time, some credits appear to generate hiring without increasing employment or to generate much more hiring than net employment growth, consistent with these credits leading to churning of employees that raises the costs of producing jobs via hiring credits.
\end{abstract}

\author{
David Neumark \\ Department of Economics \\ University of California at Irvine \\ 3151 Social Science Plaza \\ Irvine, CA 92697 \\ and NBER \\ dneumark@uci.edu \\ Diego Grijalva \\ Department of Economics \\ University of California at Irvine \\ 3151 Social Science Plaza \\ Irvine, CA 92697 \\ dgrijalv@uci.edu
}




\section{Introduction}

The Great Recession led to levels of job loss and unemployment that were the worst on record since the Great Depression (Elsby et al., 2010; Martínez-García and Koech, 2010). For most states unemployment rates climbed to higher levels than in any post-War recession, and in general the high levels of unemployment reached during the Great Recession were more persistent than in past recessions (Pittelko, 2011). Naturally, state and federal policymakers grappling with the aftermath of the Great Recession sought ways to spur job creation, in many cases adopting hiring credits to encourage employers to create new jobs. Many states enacted credits, and the Hiring Incentives to Restore Employment (HIRE) Act established a modest credit for most of 2010 at the federal level. The goal of this paper is to provide evidence on the effects on job growth of state hiring credits like those adopted during and after the Great Recession, using evidence from this period and earlier.

As summarized in Neumark (2013), there is a research literature arguing that hiring credits are ineffective (Bartik, 2001; Dickert-Conlin and Holtz-Eakin, 2000; Katz, 1998). However, most of the evidence pointing to ineffective hiring credits comes from programs that target the disadvantaged, in contrast to programs that are non-categorical or more broadly targeted, and which explicitly try to incentivize job creation, especially during recessions. There is much less evidence on more-broadlytargeted or non-categorical hiring credits that explicitly try to boost hiring in the aggregate - with essentially the only evidence coming from the federal New Jobs Tax Credit (NJTC) of the late 1970s, enacted to spur recovery from the severe recession earlier in that decade. ${ }^{1}$ This evidence is more positive, and suggests that a hiring credit that is non-categorical and creates explicit incentives for job creation can help create jobs. However, the evidence on the NJTC is very limited - both because it is dated, and because of the usual difficulties of identifying the effect of policy at the national level, stemming from the problem of constructing a counterfactual for what would have happened absent the NJTC.

As this paper documents - for the first time, to the best of our knowledge - there is an extensive

\footnotetext{
${ }^{1}$ Katz (1998) concludes that evidence from studies of the NJTC - the prime historical example of a hiring credit targeting net job creation - shows that a "temporary, noncategorical, incremental subsidy has some potential for stimulating employment growth" (p. 31). More recently, researchers have taken a stronger position on the NJTC's effectiveness (Bartik and Bishop, 2009; Bishop, 2008).
} 
set of state hiring credits. Many of these were adopted prior to the Great Recession, and more were enacted during and after the Great Recession. Yet there is virtually no empirical work on these state credits. $^{2}$ It is the combination of the conjectures (or weak evidence) about the beneficial effects of hiring credits in the context of a severe recession, coupled with the availability of information on multiple statelevel hiring credits, which provide the motivation for the question this paper addresses: whether state hiring credits of the type adopted during and after the Great Recession, as well as earlier, boost job growth. We focus on state hiring credits for which we can more reliably identify policy effects. Moreover, we estimate the differential effects of state hiring credits that vary along many dimensions, to try to reach specific conclusions about how hiring credits should be constructed to be more effective. To address this question, we devoted a great deal of effort to assembling a database of the various state hiring credits that have been enacted, and our empirical analysis is geared towards estimating the effects of the many different types of credits that have been adapted.

Finally, there is a long-standing concern that hiring credits can be very inefficient, rewarding hiring that does not create net job growth, as firms churn employees to exploit hiring credits. By looking at the effects of hiring credits on hiring as well as net job growth, we can assess the importance of these inefficiencies, and see whether particular types of credits are more or less effective at creating net job growth along with hiring. ${ }^{3}$

To be sure, there are limitations to what we can learn about the effects of hiring credits from the available data and policy variation. As we discuss later, these limitations include potential endogeneity of hiring credits, difficulties in measuring some features of hiring credits, and in some cases relatively few

\footnotetext{
${ }^{2}$ There are only a few exceptions. Bartik and Erickcek (2010) evaluate the MEGA Tax Credit Program in Michigan, which is quite different from other hiring credits. In addition, there are some evaluations of small-scale more-targeted hiring credit (or "voucher") experiments (see Burtless, 1985, and the discussion in Hollenbeck and Willke, 1991). Finally, a recent, preliminary paper (Chirinko and Wilson, 2010) estimates the effects of state hiring credits, finding some modest evidence of positive effects. They focus on some subtler issues of the timing of effects based on the effective versus the signing date of the credit. Our paper differs in numerous ways, including using a much more comprehensive database on state hiring credit programs. Indeed, we do not know which subset of the many hiring credits we capture in our database are used in the Chirinko and Wilson analysis. They report a maximum of 20 states with hiring credits in their sample period of 1990-August, 2009, far fewer than we find; and they provide no information on the type of credits in their database whereas we focus explicitly on distinctions between types of credits.

${ }^{3}$ Another potential inefficiency, which we do not address, is windfalls in the form of credits paid to firms that would have created new jobs absent the credit.
} 
instances of a particular kind of credit. While taking these limitations seriously, we would argue that given the lack of evidence on the effects of hiring credits, and such strong interest in whether government policy can spur job creation, it is important to learn what we can from the existing data and policy variation.

To summarize the findings, we find that although many types of state hiring credits did not spur job growth, some specific types of hiring credits did succeed in boosting employment. The features associated with effective credits are refundability, allowing for recapture of payments if the required goals were not met, and targeting the unemployed. Some of the results are consistent with what we might expect based on past research thinking about when credits should be more or less effective, and some of the problems hiring credits have to be able to overcome to spur job growth (see the discussion in Neumark, 2013). A refundable hiring credit ought to have a greater impact on firms because it is valuable even if the firm does not have taxable income in the current period. Recapture provisions should make hiring credits more effective. And credits targeting the unemployed, especially during a period such as the Great Recession when unemployment should not be a stigmatizing characteristic, should be more effective. ${ }^{4}$ Indeed, new evidence on federal hiring credits adopted in response to the Great Recession also suggests that, for example, credits targeting the unemployed were effective in this period (Farooq and Kugler, 2015). At the same time, some expectations are not borne out in the data. Perhaps most significantly, we do not find a stronger positive effect (or indeed any positive effect) of temporary hiring credits, although as we explain it is very difficult to determine whether a hiring credit was perceived as temporary by employers. All in all, though, the results provide some evidence that judiciously chosen hiring credits can help increase job growth, perhaps especially during severe downturns. At the same time, we find some evidence justifying concerns in the previous literature that hiring credits generate more gross hiring than net employment growth.

\section{Empirical Approach}

\footnotetext{
${ }^{4}$ Kroft et al. (2013) provide evidence consistent with this idea. In particular, they find evidence that employers pay attention to labor market conditions in interpreting unemployment as a negative signal. While employers are less likely to call back those unemployed for a longer spell, the stigmatizing effect of a long unemployment spell is weaker in a slacker labor market.
} 
The empirical strategy uses differences-in-differences, contrasting the job growth experiences of states that did and did not implement particular types of hiring credits, controlling for other factors so as to isolate the effects of state hiring credits, including a counterfactual business cycle measure (PSE, for "predicted state employment") as well as other controls $X$ discussed below. We include up to 12 lags of the hiring credit variables in our analysis of monthly data, covering one year subsequent to the adoption of the credits. ${ }^{5}$

To be more specific, denote the level of state employment as $E_{j t}$, and denote by $H C_{j t}$ a dummy variable for a hiring credit in state $j$ and period $t$. Let $T_{t}$ denote period dummy variables (for each unique month in the sample), $S_{s}$ denote state dummy variables, and $M_{r}$ denote a vector of calendar month dummy variables.

The baseline model that underlies our estimates of the effects of hiring credits on employment is:

$$
\begin{aligned}
& \ln \left(E_{j t}\right)=\alpha_{0}+\alpha_{1} t+\sum_{k=0}^{12} \beta_{k} H C_{j, t-k}+\sum_{k=0}^{12} \gamma_{k} \ln \left(P S E_{j, t-k}\right)+T_{l} \tau \\
& +\sum_{s} \sum_{r}\left\{\mu_{s r} S_{s} \times M_{r}\right\}+\sum_{s}\left\{\pi_{s} \ln \left(P S E_{j t}\right) \times S_{s}\right\}+X_{j t} \theta+\varepsilon_{j t} .
\end{aligned}
$$

In this model $H C_{j, t}$ is a dummy variable that is equal to one in the month a hiring credit turns on and every subsequent month, $H C_{j, t-1}$ is equal to one in the month after a hiring credit turns on and every subsequent month, etc. In other words, the effects of hiring credits arise contemporaneously and with a lag, and the effect persists, not changing after 12 months (unless the credit ends). ${ }^{6}$

The specification includes the counterfactual business cycle measure, $\ln (P S E)$, also with lags up to 12 months. In addition, there are time dummy variables $(T)$ for each month in the sample, to control for aggregate factors not captured in the controls. We include interactions between the state dummy variables $(S)$ and calendar month dummy variables $(M)$ to allow for different monthly patterns of

\footnotetext{
${ }^{5}$ The data on state hiring credits are discussed in the next section.

${ }^{6}$ Consistent with the effects of hiring credits arising with a lag, Perloff and Wachter (1979) present evidence suggesting that firms' knowledge about the NJTC influenced whether it affected job growth, and conclude that lack of information about the NJTC diminished its effectiveness. In addition, data on California's New Jobs Credit suggests that the number of jobs for which the credit was claimed was very low (200-300 jobs per month) in the first couple of months after it took effect but then rose to a higher level, but still quite low - about 1,500 jobs per month. (See https://www.ftb.ca.gov/businesses/New_Jobs_Credit.shtml, viewed December 21, 2012. We estimated jobs for which the credit was claimed by dividing total credits paid by the maximum $\$ 3,000$ credit per worker.)
} 
employment changes by state. ${ }^{7}$ The interactions between the counterfactual cyclical measure and the state dummy variables allow the effects of this cyclical variable to differ by state. ${ }^{8}$ State differences in the effects of the business cycle measure could arise, for example, because the same magnitude of the shock to two different states could reflect employment changes in different industries, with different cyclical sensitivity. Or states may differ in their exposure to domestic versus international markets, even if their industry composition is similar.

We estimate the model in first-differenced form, for the change in log employment (dropping the first observation for each state), to ease interpretation and to scale states similarly, using the specification:

$$
\begin{aligned}
& \Delta \ln \left(E_{j t}\right)=\alpha+\sum_{k=0}^{12} \beta_{k} \Delta H C_{j, t-k}+\sum_{k=0}^{12} \gamma_{k} \Delta \ln \left(P S E_{j, t-k}\right)+\tau_{l} T_{l} \\
& +\sum_{s} \sum_{r}\left\{\mu_{s r} S_{s} \times M_{r}\right\}+\sum_{s}\left\{\pi_{s} \Delta \ln \left(P S E_{j t}\right) \times S_{s}\right\}+\Delta X_{j t} \theta+\Delta \varepsilon_{j t} .
\end{aligned}
$$

Note that this model is equivalent to one in which we first difference all of the variables in equation (2), including the time dummy variables, the state-month interactions, etc. ${ }^{9}$ Robust inference requires clustering the data at the level of the state to allow for arbitrary patterns of serial correlation within states, and heteroscedasticity across states. With 50 states, the asymptotic approximations should provide reliable inference (Cameron et al., 2008).

The key parameters in equation (2) are the $\beta_{k}$ 's, which capture the contemporaneous and lagged effects of changes in hiring credits on employment. If hiring credits boost employment, we would expect the values of the $\beta_{k}$ 's to be positive, at least for some period. In contrast, we could find the $\beta_{k}$ 's equal to zero even if many employers claim hiring credits, when they are claiming credits for hiring that would have occurred absent the credit, or otherwise manipulating their workforces in ways that make them eligible for credits without creating jobs.

Our counterfactual business cycle measure is intended to capture cyclical influences on employment growth in each state aside from state hiring credits that may respond to the state economic

\footnotetext{
${ }^{7}$ Note that this sum is taken over all states but one, since the full set of month dummies will subsume the monthly pattern for one state, and over all months, so that these subsume the standard fixed state effects. The inclusion of the state fixed effects in the model in first differences implies that the model in levels has state-specific linear trends.

${ }^{8}$ Again, the sum is taken over all states but one since the main effects capture the effect for one state.

${ }^{9}$ That is, the dummy variables and interactions can remain in levels rather than first differenced, and the model fit is the same.
} 
cycle. We construct this counterfactual business cycle measure by applying national time-series changes in disaggregated industry employment to the state, based on the state's industry composition in a baseline period of stable aggregate economic growth (as in Bartik, 1991). To provide a simple example, if a state, at baseline, had $50 \%$ of employment in the auto industry and $50 \%$ in the restaurant industry, then the counterfactual for employment change over a given period would be an equally-weighted average of the employment change nationally in these two industries.

Data on total and industry employment come from the Quarterly Census of Employment and Wages (QCEW). ${ }^{10}$ The QCEW provides monthly employment at the state level and by NAICS industry level. To construct the counterfactual cyclical measure (PSE) we used industry employment at the NAICS 4-digit level. ${ }^{11}$ One issue is that in the disaggregated state-by-industry QCEW data the information is suppressed in some months for confidentiality reasons. In these cases, we scale up the non-missing entries proportionally to match total employment for the month. Second, to avoid noise in our baseline industry composition, we compute the baseline industry employment by averaging over all 12 months in 1990, and then divide by the average of total employment across months. Finally, we have to assign a baseline industry composition to one particular month to construct our counterfactual business cycle measure for each subsequent month, but the annual averages do not match any specific month because we have used an average of industry composition over the year. We therefore rescale industry employment so that multiplication by this average share matches June 1990 employment, and then construct the cyclical measure relative to that month. (When we look at the 2007-2011 sample to study the Great Recession period separately, we use 2006 data to construct our baseline.)

More generally, let subscripts $j$ index states, $k$ industries, and $b$ the baseline period. Denote by $S E_{j k b}$ total employment in state $j$, industry $k$, and period $b$, denote by $A E_{k t}$ aggregate (national)

employment in each period $t$ in industry $k$, and denote by $A E_{k b}$ aggregate employment in industry $k$ in the baseline period $b$. Then state employment based solely on aggregate developments is predicted in each

\footnotetext{
${ }^{10}$ These data can be downloaded at http://www.bls.gov/cew/data.htm.

${ }^{11}$ The Bureau of Labor Statistics introduced the new version NAICS 2012, which applies to the QCEW starting in 2011. However, because this changes industry classification only at lower levels of disaggregation, it does not affect our classification.
} 
period subsequent to $b$ by applying the national changes to the baseline composition, as in

$$
P S E_{j t}=\sum_{k} S E_{j k b} \times\left(\frac{A E_{k t}-A E_{k b}}{A E_{k b}}\right) .
$$

This equation predicts state employment in each period by applying the national growth rate of employment in each industry between the baseline period and that period to the baseline employment level in the corresponding industry in the state, and then aggregating, weighting by the baseline industry distribution of employment in the state. It turns out that this counterfactual business cycle measure has quite strong explanatory power for employment growth. In simple regressions of the first difference of $\log$ employment on the contemporaneous and lagged values of PSE, as in the equation above (with no other controls), for the three different sample periods we study, the $\mathrm{R}^{2}$ was between 0.63 and 0.65 ; adding the state interactions increased the $\mathrm{R}^{2}$ to around 0.66 .

We have numerous other controls in $X$. First, we want to capture other states policies that could have varied contemporaneously with state hiring credits and affected hiring. To this end, we include measures of prevailing state minimum wages (the higher of federal or state minimum wages), and measures of extended Unemployment Insurance (UI) benefits, which can be important during recessionary periods. ${ }^{12}$ Since we use a first difference model, these controls enter in first-difference form, with contemporaneous values and 12 lags of the first difference.

Second, while these two policies strike us as among the most important for job growth, we recognize that there may be other polices we fail to measure explicitly. As a result, we also include measures of the political control of states in each year, on the presumption that the types of other policies adopted may vary systematically with the political party in control. Specifically, we use a dummy indicator for each year for whether the state has a Democratic Governor. ${ }^{13}$ This is entered in levels, on

\footnotetext{
${ }^{12}$ For UI, we use Farber and Valletta's (2011) measure of the number of weeks of extended Unemployment Insurance benefits, both those added automatically from the Extended Benefits program and those from the Emergency Unemployment Compensation program. Both Farber and Valletta (2011) and Rothstein (2011) show that these recent expansions in the length of unemployment insurance led to increased unemployment durations, particularly for the long-term unemployed. These extended benefits could therefore have slowed job growth. The control variable we use is the number of weeks beyond the normal 26 weeks of Unemployment Insurance that are available in that state and month.

${ }^{13}$ These original data are from Klarner (2013), with updates provided by Klarner. We verified that the results were insensitive to a richer coding that also captured control of the institutions in the state legislature, although this precludes including Nebraska, which has a nonpartisan unicameral legislature. (Results are available upon request.)
} 
the presumption that political variables may affect the growth rate of employment, so that, effectively, the model in levels includes these variables multiplied by a time trend, leaving the level in the firstdifferenced model. ${ }^{14}$

Third, when we focus on analysis of the Great Recession period, we account for the fact that the extent of the decline and the course of the recovery in each state was strongly influenced by housing market developments. Housing market developments in each state are a potential confounding factor for a few reasons: they could have directly or indirectly affected hiring via the construction industry and spillovers from that industry; they could have spurred other responses during this period that are not captured in the controls discussed thus far, which could also affect hiring; and they could have providing advance warning to policymakers of a coming crash, that could have led them to adopt hiring credits in anticipation of labor market changes, implying a causal effect in the opposite direction of the one we are trying to estimate. To address these possibilities, for the analysis of the Great Recession period we include state-specific measures of the price run-up in the 2000-2006 period, which are correlated with and would have helped predict the extent of the decline by state. ${ }^{15}$ (We do not want to include measures of the decline in prices during the Great Recession, since that could have been influenced by the same policies.) Specifically, we construct dummy variables for the quantiles of the distribution of housing price appreciation across states, and interact these with the month dummy variables, to allow for different patterns of change by state associated with this pre-recession price appreciation.

The broader point here is that the counterfactual business cycle measure discussed above would not be expected to be sufficient to fully predict the course of the state's economy absent state hiring credits. Bartik (1991) discusses the more general issue of non-traded as opposed to traded industries, based on the concern that non-traded industries generally may not follow the national trends as well, but he shows that these actually do track quite closely. However, the problem is precisely the case where national industry trends applied to the state's industry composition miss potentially important variation.

To include all states, we feature results for the specification based on the governorship.

${ }^{14}$ This variable is measured on an annual basis. We verified that including this variable in first differences had no impact on the results. (Results available upon request.)

${ }^{15}$ We use data from the Federal Housing Finance Agency (FHFA); see http://www.fhfa.gov/DataTools/Downloads/pages/house-price-index.aspx (viewed April 24, 2015) 
The housing market is of course a strong candidate for this kind of problem, as state trends during the Great Recession period (and prior to it) diverged widely from national trends. Our reading of the evidence, and events during our sample period, is that housing market changes in the latter part of our sample period are likely the main source of large deviations of state trends from those predicted by national industry trends, and hence we control for them explicitly (see Mian and Sufi, 2010). For similar reasons, however, when we estimate our models for the 2007-2011 period, we also account for the major federal effort to boost job growth in this period, namely the American Recovery and Reinvestment Act (ARRA). ${ }^{16}$

Fourth, as one additional way of adding much richer controls to the model, we estimate specifications including a full set of Census division-month interactions. Note that the model written above include interactions between state dummy variables and calendar months. But we cannot include a full set of state-month interactions, since that is the level at which the state hiring credits vary. Nonetheless, interactions between Census divisions and the full set of months restricts all identifying variation to come from within-division variation, and hence controls for shocks or any other source of variation over time that is common to Census divisions.

We are interested in the effects of different types of hiring credits. As described in detail in the next section, we classify hiring credits along a number of dimensions, and then instead of having a single dummy variable for the presence of a hiring credit, we have multiple dummy variables for the presence of different types of hiring credits.

We also focus to some extent on the effects of hiring credits adopted during or after the Great

\footnotetext{
${ }^{16}$ The Recovery.gov website provides historical data on spending under ARRA using two different measures: obligations and outlays. Obligated funds are those that occur when a contract is assigned to a particular recipient; outlays occur only after the terms of the contract are satisfied. We use spending based on obligations because it precedes new employment creation. (Wilson's (2012) analysis of fiscal spending job multipliers uses funding announcements, which precede obligations by several months. We prefer obligations as these represent secured funds that are more closely related to new employment creation both with respect to the time at which they occur and their magnitude. In addition, we also include lags of obligated spending. In Wilson's analysis, the qualitative results are not affected by using the different measures of spending.) To be precise, our control is the log of additional monthly ARRA obligated spending from all federal agencies excluding the Department of Labor (DOL). We do not include DOL because these funds are mainly used for payment of extended and expanded UI benefits, which we already include as a control. We use agency-reported data, following Wilson (2012), who notes that agency-reported data cover all ARRA spending, while recipient-reported data cover only a little over half of it. From May 2009 until December 2011 (when our sample period ends) the total amount of obligations was $\$ 421.3$ billion, while the total amount of outlays was $\$ 365.2$ billion.
} 
Recession, because of the inherent interest in whether adopting hiring credits during steep recessions contributed to the recovery. ${ }^{17}$ As the preceding discussion of our specification makes clear, we only obtain identifying information from states where there are changes in hiring credits over the sample period. As we document in the next section, states have adopted a large number of hiring credits over recent decades, although the number adopted in the 2007-2011 period is of course smaller, limiting our identifying information when we focus on this period. Moreover, there is even less adoption of or variation in hiring credits with specific features.

Our analysis focuses on state hiring credits. As noted earlier, the federal HIRE Act, establishing a modest credit, was enacted in 2010. However, we are limited to estimating the effects of state hiring credits. In many studies of similar policies that vary at the state and federal level, if a policy exists in some states, then adopting it at the federal level provides identifying information about the effect of the policy. This requires, though, that the federal and state policies be substantively the same. In the context of state hiring credits and the HIRE Act this is decidedly not the case, because state hiring credits provide credits against state taxes, whereas the HIRE Act provided credits against federal taxes. ${ }^{18}$

Although we estimate a rich model and try to capture many important dimensions of hiring credits and factors that could be confounded with them, there are still some limitations to what we can do. First, it is possible that the endogeneity of the adoption of hiring credits biases the estimates from equation (2). We do not think there is a good instrument available for hiring credits. To the extent that they are adopted in response to shocks that hit a state's economy, these shocks cannot be excluded from the model - nor are they. And we are not aware of any political reason distinct from economic outcomes that would explain why some states adopt these credits and some do not, let alone why this might vary

\footnotetext{
${ }^{17}$ There is a related question of whether hiring credits that were already on the books when the Great Recession hit served to moderate the effects of the recession. However, since these credits would not have lowered hiring costs during the Great Recession there is no theoretical reason to expect such an effect.

${ }^{18}$ Another federal credit that changed recently is the Work Opportunities Tax Credit (WOTC). The WOTC targets veterans, short- and long-term TANF recipients, SNAP (food stamp) recipients, and others. It replaced the Targeted Jobs Tax Credit in 1996. A 2011 Act (the VOW to Hire Heroes Act) extended benefits for veteran target groups, and established new categories for veterans who have been unemployed and veterans with service-connected disabilities (http://www.doleta.gov/business/incentives/opptax/eta_default.cfm, viewed March 10, 2013). The Act was adopted in late 2011, and did not take effect until 2012. Scott (2013) reports that in 2012 veterans were fewer than 4 percent of total WOTC certifications.
} 
over time (which it would have to, given that the model includes fixed state effects). However, we are able to do a few things to address this issue. First, we examine whether lagged changes in state employment growth predict the adoption of credits. We find no such evidence, which makes it less likely that endogeneity is a concern, although it cannot be ruled out. Second, this kind of analysis cannot rule out endogenous adoption of policy based on predicted future employment growth, as opposed to lagged employment growth. With regard to this problem, we believe that including the housing price run-up controls in the analysis of the Great Recession period is a means of capturing a potentially endogenous response, because the housing price run-up could have been the basis for the predicted decline when the housing bubble burst. Third, our models effectively include state-specific linear trends (because the model in first differences has a full set of state fixed effects for the growth of employment), which can help control for prior trends associated with the adoption of credits.

A second limitation concerns our ability to capture some features of hiring credits, such as their temporary nature as perceived by firms, their value, and the overall scope of a state's hiring credit programs, of which there are often many. These limitations are discussed in the following section, where we describe the hiring credit database that we built for this research.

And third, as we also document in the next section, there is tremendous heterogeneity in hiring credits, and as a consequence for many types of hiring credits there are relatively few cases in the data. Especially for those credits that are not very common, this has to make one cautious in interpreting the estimates as reflecting the effects of credits rather than other idiosyncratic shocks that happen to be associated with the adoption of credits. This is an inherent limitation. We provide what information we can by documenting which credits occur more frequently, and also by comparing results for longer sample periods in which more credits of a particular type are sometimes adopted.

\section{The State Hiring Credits Database}

The key input into the empirical analysis is a detailed database on state hiring tax credits that we have constructed. The construction of this database, and many issues that arose, are described in detail in the Appendix. Here we note key features of this database and the state hiring credits we capture. 
States offer a complex package of incentives ranging from tax incentives based on different criteria (e.g., job creation), to financial assistance, technical support, training, incentives for creation of infrastructure, etc. Hiring credits are only a part of this set of incentives, and thus the first step in constructing the database is to define the criteria for inclusion of a program in the hiring credit database. The main criterion is that the program intends to create (or retain) jobs. We used the following criteria for the inclusion of a program in the state hiring credit database:

- The program's law or regulations require firms to create or retain jobs or to increase payroll. Programs aimed at attracting new companies to the state (e.g., headquarters programs) are also included since by definition they create new jobs and, in most cases, they include an explicit job creation requirement.

- The program is broad in the sense that it covers a large portion of the state's firms or employees. $^{19}$

- The program is targeted directly at the employer that is creating jobs. For instance, we do not include programs that foster infrastructure improvement by local governments on behalf of a business that is creating jobs.

- The program is not geographically targeted. In particular, we do not include enterprise zone programs or local hiring programs. ${ }^{20}$

- The program's costs are not borne by local governments. In particular, we do not include property tax abatements and tax-increment financing districts.

In addition, we do not include programs based on training, apprenticeships, or internships, on research and development, or those related to the film industry. Also, we do not include either agricultural or financial programs (e.g., programs that provide loans or whose benefits are reductions in the interest rate on previous loans). In contrast, we do include programs that have broad targeting by

\footnotetext{
${ }^{19}$ For instance, we do not include the Arizona's Credit for Employing National Guard Members or the Massachusetts's Jobs Incentive Payments for Certain Biotechnology Companies.

${ }^{20}$ One exception is that Kansas's Enterprise Zone Job Creation Tax Credit is included in the database, because the incentives apply statewide.
} 
industry (e.g., manufacturing), by company type (e.g., small businesses), or groups of workers (e.g., the unemployed).

The hiring credits database provides information on job creation programs in all 50 states for the period 1969-2012, for which we identified 147 hiring credits. In June, 2012, 128 of these programs were current while 19 had expired or been replaced. ${ }^{21}$ As these numbers indicate, many states have multiple credits. Figure 1 is a histogram showing the highest number of hiring credits that states had at any point in our sample period. There are 45 states that had at least one hiring credit at some point during the whole period. Five states did not have any program: Alaska, New Hampshire, South Dakota, Washington, and Wyoming. And five states had at most one program: Hawaii, Maine, Minnesota, Montana, and Oregon. The remaining 40 states had two or more hiring credits over the period, and of these, most had two to four credits. Virginia is the state with the largest number of programs (a maximum of ten during the sample period).

Table 1 provides information on when hiring credits were adopted, and their durations. Most hiring credits were created after 1989, and more than one-third were created in 2000 or later. While the table shows that many programs last for fewer than 10 years, this is driven partly by many credits being adopted in later years. Overall, state hiring credits have lasted for an average of 12.5 years. Figure 2 presents a more detailed view at the number of programs created each year.

State hiring credits differ along several dimensions, although, as noted in the Appendix, almost all (143) require the creation of new jobs. In Table 2 we provide a detailed description of the credits we analyze, and an explanation of our coding. Table 3 summarizes the distribution of hiring credits along these dimensions and Appendix Table 1 in the Appendix presents a list of all programs in our database, with their particular features. We also capture the timing of the enactment and expiration of hiring credits.

As Table 2 shows, hiring credit programs differ in a number of ways. Hiring credits can be distinguished credits based on the outcome that the programs use as the basis to determine benefits

\footnotetext{
${ }^{21}$ Two programs became ineffective after June 2012, and three additional programs became ineffective after December 2012.
} 
(number of new jobs, percentage of new payroll, percentage of new investment, or some other factor, such as square footage of new facilities).

Hiring credits vary in terms of tax savings. Credits may limit the benefit to be equal to the tax liability, or they may allow it to be higher than the tax liability. In the latter case, firms may either carry forward to future years the fraction of the benefits above the current year's tax liability, or they may receive the full amount of the benefit in the current year (the credit is refundable). Almost one-third of programs do not specify this limit and almost half provide a carry-forward provision (Table 3).

Since we are interested in the effect of hiring credits on job growth, another important dimension is the type of new jobs required. Employment required can be full-time, FTE, or part-time. In a few cases, the program does not specify the type of employment required. Full-time is the most common requirement.

State hiring credits also differ in targeting based either on employee's characteristics (unemployed, disabled, and welfare recipients) or employer's characteristics (industry, size of the firm). Around half of all hiring credits have some type of targeting.

Hiring credits present some additional characteristics that may affect their impact on job creation. First, many programs try to ensure that credits are paid for new job creation, by "recapturing" or "clawing back" some of the tax credit if net job creation is lower than required for payment of the credit. ${ }^{22}$ One might wonder whether these provisions of tax credits have any teeth. In fact there is evidence from state reports that recapture provisions are actually used, and that states do recover credits (or other financial incentives) when job creation or other goals are not met. ${ }^{23}$

\footnotetext{
${ }^{22}$ For example, the Iowa new jobs and income act states that if the Department of Revenue "determines that business has failed in any year to meet any one of the requirements of the new jobs and income Act ... the business or group of businesses is subject to repayment of all or a portion of the amount of incentives received." Similarly, the Arkansas economic development act calls for repayment of all benefits received by a business, plus penalty and interest, if it does not create the required 100 new jobs within 24 months. Both programs allow for extensions for businesses to meet job creation goals.

${ }^{23}$ See, for example, reports on clawbacks for North Carolina (http://www.nccommerce.com/Portals/0/Incentives/CLAWBACK-REPORT_Apr-2015.pdf), Indiana (https://transparency.iedc.in.gov/Additional\%20Public\%20Information/Economic\%20Incentives\%20and\%20Compl iance\%20Report\%20Period\%20ending\%20December\%2031,\%202014.pdf), Florida (http://www.floridajobs.org/business/DEO_EDP_PROD.htm, under "Quick Action Closing Fund, Inactive), Mississippi (https://merlin.state.ms.us/reports/FY2013\%20Mississippi\%20Incentives\%20Report.pdf, pp 20-11), and
} 
In addition, several hiring credits determine either eligibility for the credit or the amount of the credit based on the wage level of the new jobs. In some cases there is a minimum wage level to which they apply, thus attempting to promote the creation of higher-wage or higher-skill jobs. Some programs vary their credit values and specific provisions (such as the wage level required of new jobs) according to the county (or type of county) where the new jobs are created.

Finally, credits can differ based on whether they are temporary or permanent. While this distinction is clear at the theoretical level - and we would predict a stronger effect of a temporary credit that shifts hiring to the period when the credit applies - this difference is not so clear in practice, as discussed in the Appendix. For example, an apparently permanent credit can be repealed and a temporary one extended.

Based on these features of hiring credits, we assign to each credit a value of one or zero to denote the presence or absence of that particular feature. One potential limitation of the hiring credits database is that each program is treated equally, i.e., we do not distinguish between "small" and "large" programs. The reason is that this distinction is not clear between states or even within states. For instance the Virginia economic development incentive grant (VEDIG) requires a minimum of 200 new jobs and a capital investment of $\$ 6,500$ per job and provides a discretionary grant, while the state's Small business jobs grant fund requires only five new jobs and provides a grant of between $\$ 500$ and $\$ 2,000$ per job. Clearly, these two programs are quite different and aim at very different types of firms. Yet, it is not clear which one should have a larger impact on employment, since the latter can potentially reach many more firms. Thus, despite their differences, in the database the two programs are treated equally.

More generally, programs vary significantly within and across states. Much of this variation is of course captured in the coding discussed above, but it would be ideal to have measure of the generosity of the credits, to characterize them in terms of the strength of the incentives they create for firms using a measure like the value of the credit per worker hired. However, it turns out that there are insurmountable

Maryland

(http://business.maryland.gov/Documents/ProgramReport/MarylandEconomicDevelopmentAssistanceAuthorityAnd FundFY2011.pdf) (all viewed April 22, 2015). A list of websites providing information on penalties for noncompliance is available in Appendix 5 of Good Jobs First (2012). 
problems in trying to do this. First, the information available is very limited. Only some program laws require the state to report the amount spent as well as the number of jobs created. And even in these cases, since some programs are targeted at specific investment programs, the data are not released for confidentiality reasons. In other cases, the information is available only for some years. Second, as noted above, even when the programs provide information, they vary significantly in terms of the requirements and specific incentives for job creation provided. This implies that expenditure by a specific program is not necessarily comparable to expenditure by other programs. For example, some credits focus on investment and have a small job creation component. While we do capture this by coding the credits along various dimensions, it is not possible to define expenditure on a comparable basis.

Finally, even when this information could be comparable, it turns out that the impact on the level of employment does not increase monotonically with expenditure, even for a specific program. To see this in a specific example, Appendix Table A1 presents information on the amount spent as well as the number of jobs created by the Alabama Income Tax Capital Credit for the period 1995-2012. For this period, creating a new job costs on average $\$ 14,000$. However, according to the information provided, this amount varies from a minimum of $\$ 28.35$ in 1996 to $\$ 62,146$ in 2012. Thus, even for those programs that provide expenditure information, reported expenditures per job created is not a reliable source to measure the actual employment impact in different points in time. Furthermore, only a few programs provide information on the actual number of jobs created. Given these limitations, we define a program in terms of the characteristics discussed above, and do not try to quantify the size or scope of the credits.

Studying all dimensions of state hiring credits simultaneously is problematic and likely to lead to low precision of estimates. Rather, we present analyses for related sets of features of specific classes of hiring credits. Examples include: credits targeting the unemployed, the disabled, welfare recipients, or none of these; credits that explicitly target net job creation versus those that do not; and credits that allow for recapture or claw-backs versus those that do not. Thus, for example, for a two-way classification of hiring credits, two dummy variables $H C^{l}{ }_{j t}$ and $H C^{2}{ }_{j t}$ can be defined, and substituted for the single $H C_{j t}$ in 
equation (2) above. This allows the estimation of the effects on job growth of each type of credit within a broad class of credits. ${ }^{24}$

As we also discussed in Section III, the identifying information for the effects of state hiring credits on job growth comes from changes in state hiring credits during our sample period. As just noted, for most of our analyses we focus simply on whether a state has a particular type of credit. Thus, we need to know how many states experienced a change in whether there was a particular type of credit. This information is reported in Table 4, for the classifications of hiring credits we consider. As the table shows, for most features there is some variation in the number of states having a particular type of credit, although in many cases there is not a lot of variation.

Finally, there is an issue of how to measure hiring credits. Much of the variation in hiring credits comes from states where a program already existed, sometimes of the same type. For example, in the aggregate, of the 38 programs created from January 2006 until December 2011, 36 were added in states that already had at least one program. The remaining two were created in California and Wisconsin in 2009. This raises the question of whether additional programs of the same type provide additional incentives to firms and thus might contribute to employment creation. We have chosen to code simply the existence of a credit of a particular type, rather than the number of credits. Our sense is that the count of credits often reflects the proliferation of a number of small programs in a state that add up to similar coverage provided by single programs in other states. ${ }^{25}$ For that reason we view specifications based on the presence or absence of a particular type of hiring credit as more informative about the effects of enacting hiring credits.

\section{Results}

\section{Baseline Results}

Our baseline results are from models estimated for the 1995-2011 period. We can extend the sample back a bit earlier, to 1991, and we do so later. But data on the UI benefit extensions are available

\footnotetext{
${ }^{24}$ Nonetheless, in results available upon request we show that results are qualitatively similar and sometimes actually stronger statistically - although indeed less precise - when we estimate specifications including all the credit types simultaneously.

${ }^{25}$ For example, in Virginia there are separate credits targeting large and other businesses (the two Virginia investment partnership programs) or targeting small and other businesses (the two Jobs investment programs).
} 
beginning in 1995. Each panel in Table 5 reports estimates from a different specification. Thus, the first panel reports estimates of the effect of a hiring credit of any kind, the second distinguishes between credits based on new job growth, new payroll growth, new investment, or other criteria, etc. All specifications include a contemporaneous dummy variables (or dummy variables) for the hiring credits included, plus 12 monthly lags of these. The table report the contemporaneous coefficients, and then the cumulative effect including lags through four, eight, and 12 months; the results are not qualitatively different looking at or summing over somewhat different lag lengths.

As reported in the first panel, there is no evidence of an effect of hiring credits when no distinctions are made among the features of hiring credits. To interpret the magnitudes, the estimated coefficient of 0.0001 on the cumulative (through the 12-month lag) effect of hiring credits based on investment implies that employment is increased by very small 0.01 percent by the enactment of a hiring credit without regard to its specific features.

The second panel finds no evidence of significant positive effects of hiring credits whose benefits are based on new jobs, new payroll, or new investment. We might have expected hiring credits that provide benefits based on job growth to be the most successful at boosting employment, whereas a hiring credit based on payroll growth would not necessarily be expected to boost employment, because in the first case benefits are obtained exclusively through the creation of new jobs, while in the second case benefits may be obtained through the creation of a limited number of high-wage jobs or increasing pay for the same jobs.

The next panel distinguishes between credits based on job growth measured in terms of full-time employment, FTE, and part-time employment (as well as not specified). Most of the point estimates in this panel are negative, and some (for FTE and for part-time employment) are significant in the very short run. If there were any prediction for hiring credits broken down this way, it likely would be for a negative effect of credits based on full-time employment, which could encourage firms to combine part-time jobs into full-time jobs. A negative effect on FTE or part-time employment is a bit harder to explain, unless 
for some reason firms respond to the credit by increasing hours simultaneously with reducing the number of workers (in relative terms).

The following panel distinguishes credits based on their tax treatment. We would expect refundable credits to be the most valuable, since these give money to firms even if they do not have taxable income in the current year - a circumstance we might expect to be more frequent during or after a recession. ${ }^{26}$ The evidence is consistent with positive effects of refundable credits. For all the other taxtreatment classifications of hiring credits, the estimated effect are small and statistically insignificant, and alternate signs. However, the estimated effects of refundable credits are all positive, and become statistically significant at the 10-percent level over the longer-run. At the 12-month lag, the point estimate of 0.0044 implies that job growth is increased by 0.44 percent, which is sizable.

The first panel in the second column of the table distinguishes between credits based on whether they imposed some kind of minimum wage requirement. We might expect a larger effect for credits that do not have a wage requirement, if the wage requirement is binding. On the other hand, it is possible that higher-wage firms that meet the wage requirement anyway are more responsive to the credit. Regardless, none of the estimated effects for this specification are positive, and most are insignificant (the exception is the eight-month cumulative effect for credits with no wage requirement).

The following panel categorizes hiring credits based on whether there is a mechanism to recapture the credits if job creation goals are not met. We would expect a recapture mechanism to lead to more effective credits, either by enforcing job creation goals or encouraging only firms that could actually meet them to apply for credits. The evidence is consistent with this prediction, as the estimates for hiring credits with recapture provisions are positive, and the estimate through the eight-month lag is significant at the 10-percent level. The examples discussed earlier indicate that states can recover benefits paid when job creation goals are not met, and even if this recovery does not often occur, the threat of recovery may enhance the effects of hiring credits with recapture provisions.

\footnotetext{
${ }^{26}$ Credits with carry-forward provisions can have similar effects, if taxable income is expected in the near future.
} 
Below this specification we distinguish among credits that target specific industries, manufacturing in particular, or that do not target by industry. In no case do we find significant positive effects. Interestingly, the effects of credits targeting manufacturing are negative and significant. A possible interpretation of this result is that this kind of targeted hiring credit is more the result of political pressure than of targeting to where the potential job creation effects are highest. However, as Table 4 shows, this evidence on credits targeting manufacturing comes from only one such credit enacted in the sample period covered in Table 5, and (as shown below) is not robust to extending the sample period to include another such credit.

The next panel looks at the type of worker targeted. As noted in the Introduction, many hiring credits - and those generally deemed ineffective - have targeted the disadvantaged or disabled. What might be of more interest, especially as a counter-recessionary policy, is a hiring credit targeting the unemployed. There is no evidence of effects of hiring credits targeting welfare recipients or the disadvantaged more generally, consistent with earlier work. In contrast, hiring credits targeting the unemployed have positive effects on employment, with a short-term estimate (through four months) that is statistically significant, indicating that such credit increased employment by about 0.44 percent over this period; the effect appears to diminish, however, pointing to a temporary effect that may, in fact, be the intended effect of such a countercyclical policy.

Finally, the last panel considers temporary versus permanent credits. Theory would predict that temporary credits would have the greatest short-run effect, since they should shift hiring into the period covered by the credit. However, recall from the discussion in Section III that in practice it is very hard to classify credits as temporary or permanent. Perhaps as a result, we do not find any evidence that either type of hiring credit has an effect, or of a difference between them.

Thus, the evidence from Table 5 suggests that a few specific types of hiring credits have succeeded in boosting employment, but many did not. The effective credits include refundable hiring credits, credits that allow for recapture of payments if the required goals were not met, and credits 
targeting the unemployed, although to this point the statistical evidence for these positive effects is not strong. ${ }^{27}$

One question is whether we obtain imprecise estimates by freely estimating contemporaneous and 12 lags of the effects of hiring credits, and then adding these together to estimate the effects of credits over a given number of periods. Given that our effects sometimes grow over time, but also sometimes diminish over time, we estimated more restrictive versions of our models where the effects of hiring credits are captured in just two coefficients, which change, respectively, with terms that are linear and quadratic in months for 12 months (the lag length in equation (2)). Thus, in levels the hiring credit variable becomes:

$$
\beta_{L} \cdot \min \{(k+1), 13\} H C_{j, t}+\beta_{Q} \cdot[\min \{(k+1), 13\}]^{2} H C_{j, t}
$$

So in the month the hiring credit turns on, the linear variable in the model is $\beta_{L}$, in the next month it is $2 \beta_{L}$, etc., reaching a maximum of $13 \beta$ at the equivalent of the full lag length in equation (2), while the corresponding quadratic terms are $\beta_{Q}, 4 \beta_{Q}$, etc. The effect of $H C$ changes based on these coefficients (for example, increasing at first if $\beta_{L}$ is positive, but at a decreasing rate and perhaps diminishing if $\beta_{Q}$ is negative), reflecting a change in the effectiveness of the credit through the 13 months covered, at which point the effect stops changing. As before, we estimate the model in first differences, so the effects arise and change over the lag length of the credit variables, and then eventually revert to zero.

The resulting estimates are reported in Table 6. Focusing attention on the three credits for which we have found some consistent evidence of positive effects - refundable credits, credits with recapture provisions, and credits targeting the unemployed - there is not a notable difference in precision from these more restrictive specifications, and the estimated magnitudes are of the same order of magnitude.

\footnotetext{
${ }^{27}$ We also estimated specifications like in Table 5, but with a full set of interactions between Census division dummy variables and all calendar months, so that the variation comes fully from within Census divisions, allowing for unmeasured policy differences (or other effects) that vary regionally. The estimates are very robust. We also estimated the specifications as in Table 5 defining the hiring credit variables as counts of the number of credits with a particular feature, rather than dummy variables for the presence of a credit with a particular feature. As noted earlier, the variation in the number of credits may not be meaningful if the addition of credits of a type that already exists in a state simply indicates a proliferation of small programs that does little to change incentives to hire. Some but not all of the results persist. We no longer find any evidence of positive effects of on employment growth from refundable credits or credits allowing recapture. But we still find positive effects of credits targeting the unemployed. (Results are available from the authors upon request.)
} 
Only for credits targeting the unemployed are the coefficients statistically significant, with a positive linear and negative quadratic effect - consistent with the increasing and then diminishing effect in Table 5. In our view, there is no a priori basis for imposing the restrictions in this table, and given that doing so does not sharply increase the precision of the estimates, we prefer the unrestricted estimates. ${ }^{28}$

We also estimated models that interact the hiring credit variables with the indicator for Democratic control of the statehouse (our political control variable). We did this for the credits for which, in Table 5 and additional analyses below, we find the most consistent evidence that hiring credits increase job growth - refundable credits, credits with recapture provisions, and credits targeting the unemployed. Interestingly, in every case the interactions were positive, and generally significant for hiring credits targeting the unemployed and for refundable credits (for the longer-term cumulative effects). This could be related to unmeasured characteristics of the credits adopted when Democrats served as governor, including perhaps generosity or breadth of the credits - which, as explained earlier, we found difficult to measure. (These results are available upon request.) Thus, these specifications provide stronger evidence of positive effects of these hiring credits, although we do not feature these estimates because it is not clear why the party of the Governor is critical. Below, we consider an alternative hypothesis - that the effects of hiring credits vary over the business cycle - for which we think the predictions are clearer.

\section{Alternative Sample Periods, and the Great Recession}

Table 7 reports estimates extending the beginning of the sample period back to 1991, which necessitates dropping the UI benefit extension controls. The estimates are little changed from Table 5, which perhaps is not too surprising since there is a lot of overlap in the samples, and, to the extent that the effects of hiring credits differ during recessions - a question we turn to below - we only get a little bit more cyclical variation from the end of the recession in the early 1990s. We still find positive effects and sometimes significant effects of refundable hiring credits and credits targeting the unemployed; but the point estimates for credits with recapture provisions are smaller and no longer statistically significant.

\footnotetext{
${ }^{28}$ Restricting the effects of hiring credits to follow a linear specification only - the first term in equation (4) - led to much less precise estimates, likely because this specification does permit the diminution of effects of hiring credits over time apparent in many cases in Table 5.
} 
More interesting is restricting our focus to the period of the Great Recession, in part because of interest in the credits adopted during this period, and, perhaps more so, because of general interest in whether hiring credits can help boost job growth during a severe economic downturn. Anti-recessionary hiring credits may be more effective, especially when coming on the heels of a steep recession, because stigma effects are likely to be significantly weakened or eliminated for a credit that is either noncategorical or that targets the unemployed. Employers likely understand that many people become unemployed in a recession because of external adverse shocks to their employers, rather than because of individual low productivity, malfeasance, etc. And when employment has largely been falling, hiring credits should do more to incentivize hiring that would not have occurred absent the credit.

The estimates for the 2007-2011 period are reported in Table 8. For this period, we can reintroduce the UI benefit extension controls. And as noted earlier we add controls for ARRA spending, and for housing price appreciation prior to the Great Recession. For refundable hiring credits, the point estimates are sometimes larger than for the longer sample period, although not statistically significant. (The standard errors are a good deal larger, likely because of the much smaller sample.) The evidence for positive effects of hiring credits including recapture provisions is stronger for this subperiod. The point estimates are large and statistically significant (at the five- or 10-percent level) through four, eight, and 12 months. The same is true for hiring credits targeting the unemployed, which have positive and statistically significant effects for all of the cumulative effects reported in the table. For recapture provisions and credits targeting the unemployed, the effects are sizable. Credits with recapture provisions boosted jobs by 0.8 percent by 12 months after the adoption of such a credit, and credits targeting the unemployed by 1.16 percent. ${ }^{29}$ We do not have information on spending on such credits from the states that adopted them, but it is highly unlikely that states spent anything close to 1 percent of their economy's payroll on these credits, suggesting the benefits could well outweigh the costs. ${ }^{30}$ Finally, for the analysis

\footnotetext{
${ }^{29}$ Because the models estimated for the 2007-11 period include the additional housing appreciation and ARRA spending controls, we also estimated models for the same period excluding these controls, to provide a better comparison, based solely on the difference in sample period, with the estimates in Table 5. The resulting estimates were very similar to those reported in Table 7, and if anything a bit stronger. (The estimates are available upon request.)

${ }^{30}$ Note that the effect of ARRA spending is positive (although not significant) at long lags. This is consistent with
} 
of this period we also find a statistically significant positive effect, in the shorter-term, of hiring credits based on investment. Credits incentivizing investment may not directly subsidize hiring, but the additional investment, if it occurs, could entail more hiring. ${ }^{31}$

The stronger estimated effects of refundable credits and credits targeting the unemployed, in the 2007-11 period compared to the longer sample periods, suggests that they may have stronger effects during recessions - perhaps especially during the kind of severe downturn that characterized the Great Recession. To provide more evidence on this question, we reverted to the longest sample period (19912011), but introduced interactions between the hiring credit variables and an indicator for national recessions (based on NBER recession dates) plus a period extending one year beyond the end of each recession in this sample period, given the slow rebound of labor markets after recessions. We estimated these interactive models focusing on the three hiring credits for which we have found evidence of effects on job growth: refundable credits, credits with recapture provisions, and credits targeting the unemployed. $^{32}$

The estimates are reported in Table 9. Turning first to the latter two types of credits, for which we found stronger effects during the 2007-11 period, for credits with recapture provisions, we do not find any evidence that such credits were generally more effective during and immediately after recessions, except in the very short term. For credits targeting the unemployed, the point estimates are consistent with strong effects during and immediately after recessions. During other periods (as indicated by the main effects in the first row), the estimated effects of these credits are near zero and statistically insignificant. But during recessionary periods the point estimates are generally near 0.01 within a few months of enactment, albeit statistically significant only for the cumulative effect through four lags (we report the interaction as well as the sum of the main and interactive effects). Finally, the strongest evidence of positive effects during recessions is for refundable credits, for which the estimated effects are positive and significant in all cases, with estimates between 0.01 and 0.02 . If the tax treatment of hiring

Wilson's (2012) finding that long first-difference estimates of the effects of ARRA spending on job growth were positive, although he estimates a much different specification - including some IV estimates - and finds large positive effects that exceed substantially other estimates of job creation by the ARRA (see Neumark, 2013).

${ }^{31}$ Because the evidence for this type of credit emerges only for the 2007-11 period, we do not emphasize it as much.

32 The notes to the table give more details on the exact specification. 
credits matter, then it is perhaps not surprising that the refundability of credits is critical during recessions, since in such periods it is far more likely that companies are losing money and do not have taxable income, increasing the value of refundable credits. ${ }^{33}$ Overall, then, we have two types of evidence pointing to positive effects during recessions, perhaps especially during a very steep recession, of hiring credits that are refundable, that allow recapture, or that target the unemployed.

\section{Endogenous Determination of Hiring Credits?}

It is possible that credits are adopted in response to past changes in employment in ways that could bias the estimated effects of credits in the previous tables. For example, there could be an "Ashenfelter dip" phenomenon in which credits are adopted in response to negative shocks, from which states then recover, imparting a positive bias to our estimated effects of hiring credits. Alternatively, credit adoption could be associated with underlying employment trends, with negative trends implying downward bias, and positive trends upward bias. However, we already noted that the models include state-specific linear trends.

To try to assess whether endogenous determination of hiring credits based on past changes in job growth drives our results, we estimated regression models for adoption of hiring credits. We include the same control variables, as well as long lags of the first differences of log employment (up to 36 months). We did this for the credits corresponding to what we regard as the most interesting findings thus far refundable credits, credits that allow recapture, and credits targeting the unemployed. And we do this for the different sample periods and specifications we have considered. As reported in Table 10, we find virtually no evidence of statistically significant relationships between past employment change and credit adoption (there is one exception in the last column). Thus, the estimates in the table imply weak associations between past employment changes and credit adoption, making it unlikely that there are biases from endogenous adoption of credits. Moreover, there is a pattern of much weaker associations in the shorter-term (say, through six or 12 months) than in the longer-term, making it even less likely that the changes in employment after credits are adopted are in fact driven by earlier employment changes that

\footnotetext{
${ }^{33}$ Credits with carry-forward provisions could also matter, if these companies expect to survive the recession, but we did not find such evidence.
} 
drove credit adoption. We also report the estimated effect of the political control variable in Table 10. It is never statistically significant, and the sign varies across different lags and samples.

\section{Statistical Significance}

Our analysis of the effects of state hiring credits based on the statistical evidence we have discussed the far leads to a few tentative conclusions. First, many types of hiring credits we study do not have statistically significant effects on job growth. Second, however, there is evidence that refundable hiring credits, credits with recapture provisions, and credits targeting the unemployed, boosted job growth, particularly during recessions or even more so during the Great Recession.

Two issues arise in thinking about statistical significance of the findings. First, is the negative conclusion regarding other hiring credits because of imprecise estimates - cases where the point estimates are generally positive and non-negligible, but the estimates are not sufficiently precise to be statistically significant? This is an issue that sometimes receives too little attention in empirical analyses of public policies: In particular, if evidence points to positive effects (in this case), but the estimates are not statistically significant, is a conclusion of "no evidence of an effect" one that might lead policymakers to forego a policy that might have benefits?

In our view, a lack of precision is not the explanation of the absence of positive, significant findings for many of the other types of hiring credits we study. To see this, look at Tables 5, 7, and 8 (the estimates for the three sample periods we consider), and put aside the types of hiring credits for which we sometimes find significant positive effects - credits based on investment, refundable credits, credits with recapture, and credits targeting the unemployed. Across the three tables, for all of the other features of hiring credits we consider, the estimated signs of the effects of hiring credits vary in sign or are negative, and are very small, with the only exception of the hiring credits based on investment. Thus, in almost every case, a more reasonable conclusion is that the true effect is very near zero.

The second issue is in some sense the opposite. Given that we study many type of hiring credits, are the statistically significant effects that emerge for refundable credits, credits with recapture provisions, and credits targeting the unemployed indicative of real policy effects, or are they just chance occurrences? 
This is an example of the "multiple testing" problem (e.g., Anderson, 2008). The formal statistical treatment of this problem entails adjusting the critical values to account for the fact that one is testing multiple hypotheses simultaneously, and hence conventional critical values based on single hypothesis tests are understated, and thus statistical significance of the estimated effects overstated, with too-frequent rejections of the null hypothesis.

Our analysis of this question, for the three hiring credits with positive results, is reported in Table 11. There, we report, for each of our three sample periods, whether or not we reject the null hypothesis of no effect, first using the conventional p-value from the single test of a coefficient (or sum of coefficients, in the case of lags), and then using two different multiple testing procedures based on all the estimates (and associated p-values from individual tests) shown in the corresponding Tables 5,7 , and $8 .{ }^{34}$ As we would expect, in some cases we reject in the former case, but not the latter. In particular, for the longer sample periods beginning in either 1991 or 1995 , for which the evidence was always weaker, the multiple testing procedures never lead to rejection of the null hypothesis of no effect. However, for the Great Recession period things are reversed. For credits with recapture provisions, in one case (for the cumulative effect through four months), with one of the two multiple testing methods we still reject the null of no effect, even at the five-percent significance level. ${ }^{35}$ And for credits targeting the unemployed we often reject the null hypothesis using either method, and for cumulative effects through different numbers of lags.

Taken at face value, then, the multiple testing results weaken our findings, leaving us only with significant effects of two types of hiring credits - those with recapture provisions, and more so those targeting the unemployed - and only for the Great Recession period. However, we think the multiple

\footnotetext{
${ }^{34}$ The Sidak procedure controls the "family-wise error rate," like the Bonferroni method, but is more appropriate to our case which is based on p-values from a set of two-tailed tests based on normally distributed test statistics. The Simes procedure instead controls the "false discovery rate," which is a less conservative approach, as reflected in the results reported in the table. Newson and The ALSPAC Study Team (2013) characterize the general difference between these approaches as, for an uncorrected $p$-value of 0.05 , for example, being 95 percent confident that all rejected hypotheses are false (family-wise error rate) versus being 95 percent confident that at least some of the rejected hypotheses are false (false discovery rate), and discuss the merits and shortcomings of these two approaches.

${ }^{35}$ Because the results for the Great Recession period are stronger, we show results for both the five- and the 10percent significance levels for this period.
} 
testing procedure may be too conservative in rejecting the null hypothesis of no effect for these two types of credits as well as refundable credits, for two reasons. First, as discussed earlier, there are theoretical reasons to expect positive effects of hiring credits targeting the unemployed, perhaps especially during recessions. In addition, given what we know about the ineffectiveness of many hiring credits, we would expect recapture provisions to matter. And refundable credits should be the most valuable, again more so during recessions. It is true that there are theoretical predictions that other types of credits - including temporary credits, and credits based on full-time jobs created - should be positive. But in the former case, at least, we explained why the actual classification of credits as permanent versus temporary is difficult.

The upshot is that we do not think that the types of credits for which we tend to find positive employment effects fit a pattern of randomness. Moreover, the results are somewhat consistent across different sample periods. Thus, while we believe the multiple testing results are interesting, we do not necessarily regard them as definitive in our case. Individual readers have to weigh the alternative interpretations of the evidence, based in part, we think, on how much they think the credits for which we find positive effects accord with theoretical expectations. Nonetheless, the results show that even if one does regard the multiple testing results as definitive, there is still statistical evidence for positive effects of hiring credits targeting the unemployed during severe recessions, and perhaps also of credits with recapture provisions.

\section{Employment vs. Hiring}

As noted earlier, one potential problem with hiring credits is that they can lead firms to churn workers, earning more credits for hiring (and firing) workers with little of the intended impact on net employment growth. We have already established some evidence of positive employment effects, so there is no reason to believe that the hiring credits we study generate only churning, with no change in employment. However, whether or not hiring credits generate a lot of churning is still an important policy question because it can drive up the costs of using hiring credits, per job created. And we have seen that for many types of credits, there is no evidence of positive employment effects. By using data 
from the Quarterly Workforce Indicators (QWI), we can learn something about churning, because these data allow measurement of hiring. We do this analysis for the 2007-2011 period, because the QWI data do not provide a balanced panel before the mid-2000s.

The QWI data also have information on separations, but the Job Openings and Labor Turnover Survey (JOLTS) data show that quits are generally more than 50 percent of separations, although of course less so during and after the Great Recession, when layoffs and discharges rose. ${ }^{36}$ Given that we cannot separate out involuntary separations that firms could use, along with hiring, to churn workers, we present evidence only on hiring (and employment in the QWI, for comparability). ${ }^{37}$

The model is the same as the one used for the monthly data, but now the time unit is a quarter, and this entails some modifications. We use as dependent variables the first difference of the log of employment (number of jobs) at the beginning of the quarter, and of the number of workers who started a new job in the quarter. The specification includes the first difference and four lags of the variable capturing the existence of a job credit (or of a credit with a particular feature); this way the lags cover the same period as our earlier specifications using monthly QCEW data. This variable is constructed from the monthly dummies and is equal to $1 / 3,2 / 3$, and one if the credit (or a credit with a particular feature) is present in a state for one, two, or three months in a given quarter. The specification also includes the first difference of the log of the state-specific shock variable and four lags. This variable is constructed as the average of the monthly shock variables in each quarter. In addition, the specification includes: interactions of the first difference of the shock variable with state dummy variables; first differences by quarter and four lags of the minimum wage prevailing in the state at the beginning of the quarter; first differences by quarter and four lags of the control for extended UI benefits; dummy variables for each

\footnotetext{
${ }^{36}$ See http://research.stlouisfed.org/fred2/categories/32241 (viewed February 11, 2013).

${ }^{37}$ The QWI data are derived from the Longitudinal Employer-Household Dynamics (LEHD) Program at the U.S. Census Bureau. The employer and workplace reports are the same as the data reported to the BLS as part of the QCEW, although the two sources are not exactly equal. Moreover, by using the linked employer information in the LEHD, accessions of workers to new employers, and separations from those employers, can be observed. Beginning of period employment is conceptually and empirically similar to QCEW month one employment. Formally, a person is defined as employed at the beginning of a quarter when he has positive earnings with the same employer in both the previous and current quarters. Hires are recorded when an individual has positive earnings with a particular employer in the current quarter and not in the previous one. There is also a "new hiring" variable defined when an individual has positive earnings in the current quarter, with no earnings from the same employer during the previous four quarters, but here we use the "all hiring" measure.
} 
quarter in the sample; and interactions between calendar quarter dummy variables and state dummy variables.

Even though hiring is a (gross) flow into employment, we estimate the model for the change in hiring, paralleling the specifications for the change in employment. The question we are asking is if a hiring credit boosts the hiring response relative to the employment response, so that firms can claim more credits when they increase hiring. ${ }^{38}$ First consider employment. When the credit is introduced, employment should grow because the cost of labor has fallen for firms where employment is growing (and which are therefore eligible for credit). In the steady state some firms are growing and some are shrinking for random reasons. The growing firms are always eligible for the credit which means that, on average, the cost of labor has declined. So we should see a permanently higher level of employment when a credit is in place. However, the growth in employment should occur over some limited period; that is, there is no reason the credit boosts the rate of employment growth permanently. Now consider hiring. When employment is growing, firms have to at a minimum hire a number equal to employment growth. If there is an incentive to churn, then they hire more (and fire some, which we do not measure). They also may have to hire more than the net employment growth because of worker attrition, so a slightly higher effect of a credit on the change in hiring than the change in employment would not be indicative of churning.

Therefore we should look at the change in hiring in the period when there is a change in employment, and compare magnitudes. Once employment growth stops, then again some firms are always growing, and they have an incentive to churn because they are eligible for the credit. So hiring, like employment, should be at a permanently higher level. Moreover, if we introduce attrition, then a higher employment level in the long run has to be associated with a higher level of hiring even absent churning incentives. However, the change in hiring (i.e., when hiring increases) should occur at the same time as the change in employment. If we instead regress the level of hiring on the change in the hiring

\footnotetext{
${ }^{38}$ In firm-level data we could test this directly, estimating a regression of hiring on the change in employment and the change in employment interacted with eligibility for a credit. That is, for given net employment growth, is gross employment growth greater when there is a credit? But in aggregate data this regression would not make sense, as there is likely always some hiring occurring, even when total employment is shrinking, and hence some firms are always eligible for a credit.
} 
credit, we do not see the higher churning associated with the employment increase, because hiring should be higher even when the credit is not changing. The longer-term effects of hiring credits on employment and hiring are of interest. However, it seems likely that the main effects of hiring credits will arise, and be detectable, in the period when the credits are implemented and induce a reduction in labor costs for firms - including those induced to increase employment (and hiring) because of the credit.

The results for employment and hires are reported, respectively, in Tables 12 and 13. Some of the employment results are quite comparable to Table 8, which is not surprising, since the QWI and QCEW reflect the same underlying data. In particular, the recapture estimates are strongly positive, and the estimates for credits targeting the unemployed are positive, although a bit smaller with larger standard errors, and hence not significant. The estimated coefficients for refundable credits - which were the weakest results in Table 7 - are no longer positive, nor are the estimates for credits based on investment. There is also still evidence of negative effects of hiring credits targeting manufacturing. Where there is evidence of an effect of hiring credits in Table 12, the effect is often larger than in Table 8, likely because the data are quarterly.

Table 13 turns to our main evidence from the QWI data, on hires. To some extent these results reflect the employment results. In particular, credits allowing recapture and credits targeting the unemployed have large and significant positive effects. In both cases, however, the positive estimates are about ten (or more) times as large as the effects on employment overall, suggesting that there may be considerably churning generated by these credits. Note also that the negative results indicate that, even with recapture provisions, firms seem to be able to claim credits for a good deal of hiring that does not create new jobs on net.

There is also some evidence of positive effects of particular types of hiring credits on hiring for which there was no evidence of positive effects on employment growth. This is the case, for example, for credits targeting the disabled and credits based on payroll growth. Thus, these latter results are consistent 
with credits in some cases leading to churning that spurs hiring but does not generate employment growth. $^{39}$

\section{$\underline{\text { V. Conclusions }}$}

State and federal policymakers grappling with the aftermath of the Great Recession sought ways to spur job creation, in many cases adopting hiring credits to encourage employers to create new jobs. This paper provides new evidence on the effects of state hiring credits on job growth, both over the longer term and also focusing in part on the influence of credits adopted during and after the Great Recession. We find that many types of state hiring credits did not spur job growth, although specific types of hiring credits succeeded in boosting employment. The features associated with effective credits are refundability allowing for recapture of payments if the required goals were not met, and targeting the unemployed. There is some evidence that the effects of these credits were stronger during and just after the Great Recession, and evidence that refundable credits and credits targeting the unemployed were more effective at promoting job growth during recessions generally. This state-level evidence complements some recent evidence on positive impacts of federal hiring credits adopted in response to the Great Recession (Farooq and Kugler, 2015).

There are some limitations to what can be learned about the effects of credits enacted in this period, in part because of the many kinds of credits that have been adopted, as well as difficulties in measuring all of their relevant features - especially generosity or the magnitude of incentives. Moreover, there is a dearth of other evidence on the effects of hiring credit programs. As a result, the findings should be interpreted cautiously.

Nonetheless, the results do provide some evidence that particular types of hiring credits may have boosted job growth, more so during the Great Recession and perhaps also other recessions. Moreover, some of the results are consistent with what we might expect. A refundable hiring credit ought to have a greater impact on firms because it is valuable even if the firm does not have taxable income in the current period, which is more likely to be true during recessions. Recapture provisions should make hiring

\footnotetext{
${ }^{39}$ Unfortunately, the limited number of hiring credits precludes asking some interesting questions suggested by the evidence, such as whether recapture provisions reduce the extent to which other types of credits generate hiring but not net job creation.
} 
credits more effective. And credits targeting the unemployed, especially during a period such as the Great Recession when unemployment should not be a stigmatizing characteristic, should be more effective. At the same time, some expectations are not borne out in the data. Perhaps most significantly, we do not find a stronger positive effect (or indeed any positive effect) of temporary hiring credits, although as we have explained it is very difficult to determine whether a hiring credit was perceived as temporary by employers. All in all, though, the results provide some evidence that judiciously chosen hiring credits help increase job growth, especially during recessions.

There is also some evidence justifying the concern that hiring credits generate more gross hiring than net employment growth. As discussed in Neumark (2013), estimates from the existing literature suggest that for every 10 hires for which hiring credits are paid, one net job is created. Nonetheless, inefficiencies this high can still be consistent with costs per job created in the United States in the $\$ 30,000$ or $\$ 40,000$ range, for example, if the credits pay $\$ 3,000$ to $\$ 4,000$ per hire - costs that are likely substantially below the costs of creating jobs through the fiscal stimulus in the form of the ARRA used to counter the Great Recession. And the evidence gives a little guidance as to the kinds of features of hiring credits likely to make them effective.

All in all, the evidence is not overwhelming that hiring credits should be (or should have been) an important part of the policy response to the Great Recession, or should be part of the response to future recessions more generally. But there is some evidence pointing in this direction, especially for particular types of hiring credits. Given these findings, there may be merit to enacting legislation establishing welldesigned federal or state hiring credits that turn on automatically and aggressively when economic downturns occur. Such credits would complement other "automatic stabilizers" that seek to boost workers' and families' incomes when a recession occurs, such as Unemployment Insurance, welfare, and progressive taxation. However, for reasons discussed in the paper, we clearly recognize that there are some limitations to our evidence, and more work is needed to provide more definitive evidence on the causal effects of hiring credits - whether adopted in response to recessions, or more generally. 


\section{References}

Anderson, Michael L. 2008. "Multiple Inference and Gender Differences in the Effects of Early Intervention: A Reevaluation of the Abecedarian, Perry Preschool, and Early Training Projects." Journal of the American Statistical Association, Vol. 103, Issue 484, pp. 1481-95.

Bartik, Timothy J. 1991. Who Benefits from State and Local Economic Development Policies? Kalamazoo, MI: W.E. Upjohn Institute for Employment Research.

Bartik, Timothy J. 2001. Jobs for the Poor: Can Labor Demand Policies Help? New York: Russell Sage Foundation.

Bartik, Timothy J., and John H. Bishop. 2009. “The Job Creation Tax Credit: Dismal Projections for Employment Call for a Quick, Efficient, and Effective Response.” Economic Policy Institute Briefing Paper No.248, Washington, DC, October 20.

Bartik, Timothy J., and George Erickcek. 2010. "The Employment and Fiscal Effects of Michigan's MEGA Tax Credit Program.” Upjohn Institute Working Paper No.10-164.

Bishop, John. 2008. "The 1977-78 New Jobs Tax Credit Was a Big Success. Can a Tax Credit for Employment Growth in 2009 and 2010 Restore Animal Spirits and Help Jump Start the Economy." Cornell University, http://digitalcommons.ilr.cornell.edu/cgi/viewcontent.cgi?article $=1185 \&$ context $=$ articles (viewed December 21, 2010).

BLS \& Co. n.d. State Economic Development Incentives and Demographic Profiles. Available at http://www.blsstrategies.com/state-incentives (viewed June 12, 2012).

Burtless, Gary. 1985. “Are Targeted Wage Subsidies Harmful? Evidence from a Wage Voucher Experiment. "Industrial and Labor Relations Review, Vol.39, No.1, October, pp. 105-14.

Business Facilities. n.d. States Incentives Guide. Available at http://businessfacilities.com/specialreport/2011-incentives-guide/ (viewed June 12, 2012).

Cameron, A. Colin, Jonah B. Gelbach, and Douglas L. Miller, Douglas L. 2008. "Bootstrap-Based Improvements for Inference with Clustered Errors." Review of Economics and Statistics, Vol.90, No.3, August, 414-427.

Chirinko, Robert S., and Daniel J. Wilson. 2010. "Job Creation Tax Credits and Job Growth: Whether, When, and Where?” Federal Reserve Bank of San Francisco Working Paper 2010-25.

Dickert-Conlin, Stacy, and Douglas Holtz-Eakin. 2000. "Employee-Based Versus Employer-Based Subsidies to Low-Wage Workers: A Public Finance Perspective." In David E. Card and Rebecca M. Blank, eds., Finding Jobs: Work and Welfare Reform. New York: Russell Sage Foundation, pp. 262-94.

Elsby, Michael, Bart Hobijn, and Aysegul Sahin. 2010. "The Labor Market in the Great Recession.” Unpublished manuscript, Brookings Institution.

Fahey, Jennifer Campbell, Janine E. Kaczmarowski, and Dorothy Krauss. 1997. "States Use Several Methods to Attract and Retain Business.” Journal of State Taxation, Vol. 16, No. 1, Summer, pp. 45-78.

Farber, Henry, and Robert Valletta. 2011. "Extended Unemployment Insurance and Unemployment Duration in the Great Recession: The U.S. Experience." Unpublished manuscript. 
Farooq, Ammar, and Adriana Kugler. 2015. "What Factors Contributed to Changes in Employment During and After the Great Recession." IZA Journal of Labor Policy, 4:3, on-line.

Good Jobs First. 2012. Money-Back Guarantees for Taxpayers: Clawbacks and Other Enforcement Safeguards in State Economic Development Subsidy Programs. Washington, DC: Good Jobs First.

Hollenbeck, Kevin M., and Richard J. Willke. 1991. "The Employment and Earnings Impact of the Targeted Jobs Tax Credit.” Upjohn Institute Staff Working Paper 91-07, Kalamazoo, MI: W.E. Upjohn Institute for Employment Research.

Katz, Lawrence F. 1998. "Wage Subsidies for the Disadvantaged." In Richard B. Freeman and Peter Gottschalk, eds., Generating Jobs: How to Increase Demand for Less-Skilled Workers. New York, NY: Russell Sage Foundation, pp. 21-53.

Klarner, Carl. 2013. "State Partisan Balance Data, 1937 - 2011.” Available at http://hdl.handle.net/1902.1/20403 IQSS Dataverse Network (Distributor) V1 (Version).

Kroft, Kory, Fabian Lange, and Matthew J. Notowidigdo. 2013. "Duration Dependence and Labor Market Conditions: Evidence from a Field Experiment." Quarterly Journal of Economics, Vol. 128, No. 3, August, pp. 1123-67.

Martínez-García, Enrique, and Janet Koech. 2010. "A Historical Look at the Labor Market During Recessions.” Economic Letter, Federal Reserve Bank of Dallas, Vol.5, No.1, January.

Mattera, Philip, Thomas Cafcas, Leigh McIlvaine, Andrew Seifter, and Kasia Tarczynska. 2011. Money for Something: Job Creation and Job Quality Standards in State Economic Development Subsidy Programs, Good Jobs First, available at http://www.goodjobsfirst.org/sites/default/files/docs/pdf/moneyforsomething.pdf (viewed Nov. 5, 2012).

Mian, Atif, and Amir Sufi. 2010. "Household Leverage and the Recession of 2007-09." IMF Economic Review, Vol. 58, No. 1, pp. 74-117.

National Association of State Development Agencies. 1983. Directory of Incentives for Business Investment and Development in the United States: A State-By-State Guide, $1^{\text {st }}$ ed. Washington D.C.: The Urban Institute Press.

National Association of State Development Agencies. 1986. Directory of Incentives for Business Investment and Development in the United States: A State-By-State Guide, $2^{\text {nd }}$ ed. Washington D.C.: The Urban Institute Press.

National Association of State Development Agencies. 1991. Directory of Incentives for Business Investment and Development in the United States: A State-By-State Guide, $3^{\text {rd }}$ ed. Washington D.C.: The Urban Institute Press.

National Association of State Development Agencies. 2003. State by State Guide to Incentives for Business Investment and Development. Austin: Summers Press.

Neumark, David. 2013. "Spurring Job Creation in Response to Severe Recessions: Reconsidering Hiring Credits." Journal of Policy Analysis \& Management, Vol. 32, No. 1, pp. 142-71.

Newson, Roger, and The ALSPAC Study Team. 2003. "Multiple-Test Procedures and Smile Plots." The Stata Journal, Vol. 3, No. 2, pp. 109-32.

Perloff, Jeffrey M., and Michael L. Wachter. 1979. “The New Jobs Tax Credit: An Evaluation of the 
1977-78 Wage Subsidy Program." American Economic Review Papers and Proceedings, Vol. 69, No. 5, pp. 173-179.

Pittelko, Brian. 2011. “Trends in States' Unemployment Rates.” The Upjohn Institute Blog, April 22. Available at http://www.upjohninst.org/blog (viewed April 26, 2011).

Rogers, Cami. 1998. "State Guidelines: The Jobs Creation Tax Credit.” Journal of State Taxation, Vol.16, Winter, pp. 44-63.

Rothstein, Jesse. 2011. "Unemployment Insurance and Job Search in the Great Recession.” Brookings Papers on Economic Activity, Fall, pp. 143-213.

Scott, Christine. 2013. “The Work Opportunities Tax Credit (WOTC).” Washington, DC: Congressional Research Service.

Sierra Group. n.d. Employment Incentives. Available at http://www.employmentincentives.com/state_incentives/state_incentives_intro.htm.(viewedJune 12, 2012).

State Capital Group. 2010. Incentives for Businesses 50 State Handbook. Available at http://www.statecapitalgroup.org/newspublications/businessincentives/BusinessIncentives2010_Final.pdf (viewed June 16, 2012).

Wilson, Daniel. 2012. "Fiscal Spending Job Multipliers: Evidence from the 2009 American Recovery and Reinvestment Act." American Economic Journal: Economic Policy, Vol. 4, No. 3, November, pp. 251282. 
Figure 1: Total Number of States with Hiring Credits at Any Time, 1969June, 2012

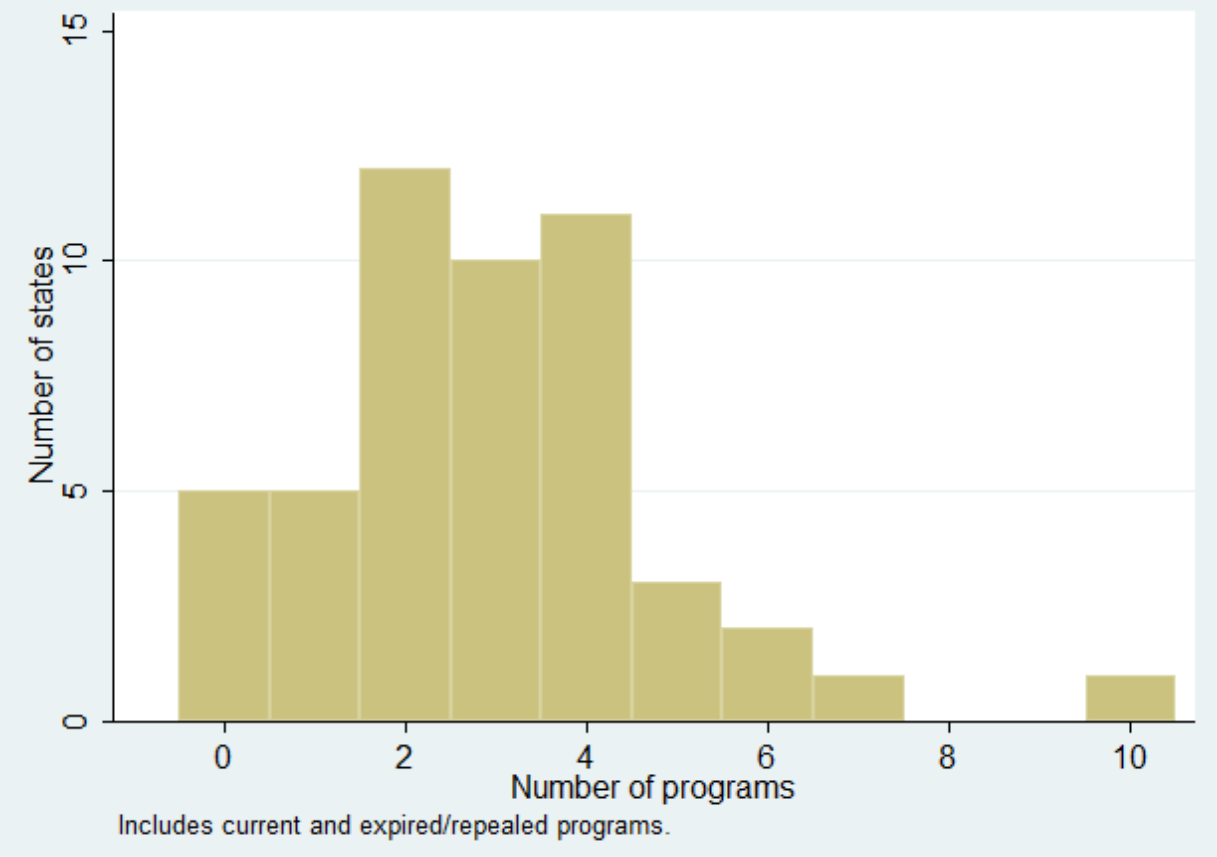

Figure 2: Number of New Hiring Credits Each Year

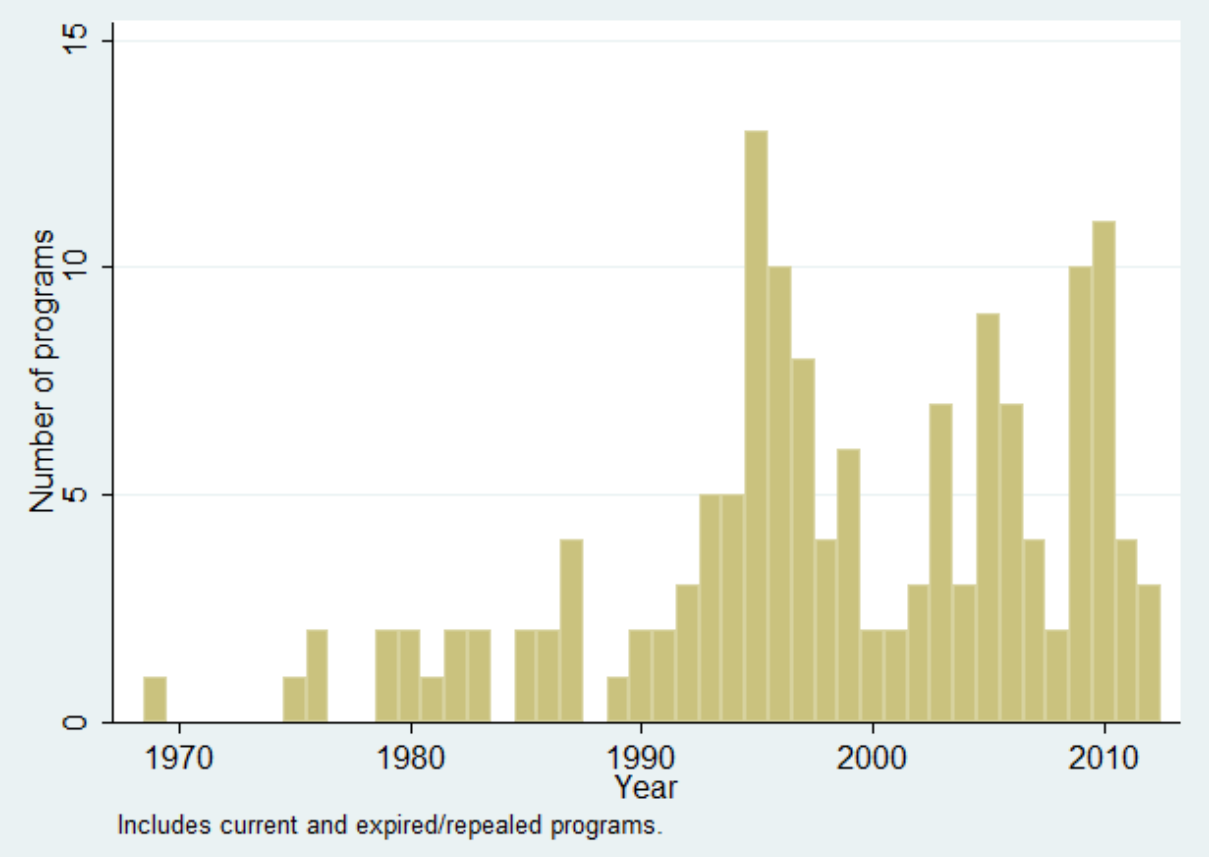


Table 1: Summary of State Hiring Credits, 1969-June, 2012

\begin{tabular}{|l|c|}
\hline A. States & \\
\hline States analyzed & 50 \\
\hline 1 or more hiring credits & 45 \\
\hline No hiring credit & 5 \\
\hline B. Basic information & 147 \\
\hline Total number of hiring credit programs & \\
\hline Creation date & 6 \\
\hline $1969-1979$ & 16 \\
\hline $1980-1989$ & 58 \\
\hline $1990-1999$ & 37 \\
\hline 2000 -before Great Recession & 9 \\
\hline During Great Recession & 21 \\
\hline After Great Recession & 121 \\
\hline Current as of June 2012 & 73 \\
\hline Duration of hiring credit programs & 53 \\
\hline $0-10$ years & 13 \\
\hline $11-20$ years & 8 \\
\hline $21-30$ years & \\
\hline $31+$ years & \\
\hline
\end{tabular}


Table 2: Definition and Coding of State Hiring Credits

\begin{tabular}{|c|c|c|}
\hline Variable & Categories & Description \\
\hline \multirow{4}{*}{$\begin{array}{l}\text { Basis for providing benefits: } \\
\text { Basis for calculating the value of credits } \\
\text { to the firm. }\end{array}$} & New jobs & $\begin{array}{l}\text { Benefit is based on the number of net new } \\
\text { employees. }\end{array}$ \\
\hline & New payroll & $\begin{array}{l}\text { Benefit is based on new payroll (wages paid to } \\
\text { new employees, withholdings of new employees). }\end{array}$ \\
\hline & New investment & $\begin{array}{l}\text { Benefit is based on new investment in machinery, } \\
\text { property, facilities, equipment or any growth- } \\
\text { related assets. }\end{array}$ \\
\hline & Other criteria & $\begin{array}{l}\text { Benefit is based on other criteria(property tax, } \\
\text { sales tax, excise tax). }\end{array}$ \\
\hline \multirow{4}{*}{$\begin{array}{l}\text { Tax treatment: } \\
\text { Form in which the program limits the } \\
\text { economic benefits provided for each } \\
\text { taxable year. }\end{array}$} & Equal to tax owed & $\begin{array}{l}\text { The maximum benefit that can be paid to a firm is } \\
\text { the firm's tax liability. }\end{array}$ \\
\hline & Carry-forward & $\begin{array}{l}\text { If the value of the benefit exceeds the firm's tax } \\
\text { liability (or a specific percentage of it) for the } \\
\text { taxable year, this excess may be carried forward } \\
\text { to succeeding years and be used as a credit } \\
\text { against the firm's future tax liability. }\end{array}$ \\
\hline & Refundable & $\begin{array}{l}\text { The whole benefit is paid even if it is higher than } \\
\text { the value of the firm's tax liability. }\end{array}$ \\
\hline & Not specified & \\
\hline \multirow{4}{*}{$\begin{array}{l}\text { Type of new jobs required: } \\
\text { The type of job the firm needs to create to } \\
\text { obtain the benefits of the program. The } \\
\text { type of job is defined by the minimum } \\
\text { number of hours of work performed per } \\
\text { week. }\end{array}$} & Full-time & $\begin{array}{l}\text { New employee works for } 30 \text { or more hours per } \\
\text { week. }\end{array}$ \\
\hline & Full-time equivalent & $\begin{array}{l}\text { One or more new employees work a number of } \\
\text { hours per week that add up to one full-time } \\
\text { employee's hours requirement. }\end{array}$ \\
\hline & Part-time & New employee works at least 10 hours per week. \\
\hline & Not specified & \\
\hline \multirow[t]{3}{*}{ Industry targeting: } & Targeted & Program applies to a cluster of industries. \\
\hline & Manufacturing & Program applies to manufacturing facilities. \\
\hline & Not targeted & Program applies to all industries. \\
\hline \multirow[t]{4}{*}{ Targeting by type of business: } & Small business & $\begin{array}{l}\text { Program applies to firms with } 50 \text { employees or } \\
\text { fewer. }\end{array}$ \\
\hline & Large business & $\begin{array}{l}\text { Program applies to firms with a large number of } \\
\text { employees, or high job creation, payroll, and/or } \\
\text { investment broadly defined. }\end{array}$ \\
\hline & Headquarters & $\begin{array}{l}\text { Program applies to those facilities where the } \\
\text { principal offices of an eligible business are } \\
\text { located. }\end{array}$ \\
\hline & Not targeted & Program applies to all types of businesses. \\
\hline \multirow[t]{4}{*}{ Targeting by type of worker: $^{\mathrm{a}}$} & Disabled & $\begin{array}{l}\text { Program applies to disabled workers, i.e., } \\
\text { individuals who are considered to have a physical } \\
\text { or mental disability which results in a substantial } \\
\text { handicap to employment. This disability may be } \\
\text { determined or certified by specific institutions such } \\
\text { as the Division of Rehabilitation Services. }\end{array}$ \\
\hline & Unemployed & $\begin{array}{l}\text { Program applies to the unemployed, i.e., } \\
\text { individuals who attest not to be working and who } \\
\text { have received unemployment compensation } \\
\text { benefits and/or have been classified as } \\
\text { unemployed by a competent office of employment. }\end{array}$ \\
\hline & Welfare recipients & $\begin{array}{l}\text { Program applies to recipients of welfare aid, e.g., } \\
\text { Temporary Assistance for Needy Families. }\end{array}$ \\
\hline & Not targeted & Program applies to all workers. \\
\hline
\end{tabular}




\begin{tabular}{|c|c|}
\hline \multirow{2}{*}{$\begin{array}{l}\text { Variable } \\
\text { Recapture provisions: }\end{array}$} & \begin{tabular}{|l|l|} 
Categories & Description \\
\end{tabular} \\
\hline & Yes \\
\hline $\begin{array}{l}\text { Program has specific provisions (e.g., } \\
\text { penalties) if the requirements to obtain the } \\
\text { credit were not met and/or maintained. }\end{array}$ & No/not specified \\
\hline \multirow{3}{*}{$\begin{array}{l}\text { Wage requirements: } \\
\text { Firms must pay a wage at or above a } \\
\text { specified level to the new and/or retained } \\
\text { employees. The wage may be defined as a } \\
\text { specific level, or a percentage of the } \\
\text { minimum wage or some average wage } \\
\text { (e.g., county, state). }\end{array}$} & Yes \\
\hline & \\
\hline & No \\
\hline \multirow{2}{*}{$\begin{array}{l}\text { Geographic provisions: } \\
\text { Program provides different benefits based } \\
\text { on location within the state (e.g., specific } \\
\text { types of counties) }\end{array}$} & Yes \\
\hline & No \\
\hline \multirow{3}{*}{$\begin{array}{l}\text { Temporary/permanent: } \\
\text { The program is originally enacted as } \\
\text { temporary, permanent, or } \\
\text { undetermined/not determinable. The } \\
\text { classification is assumed to be a feature of } \\
\text { each program throughout its duration. }\end{array}$} & Temporary \\
\hline & Permanent \\
\hline & Undetermined/not determinable \\
\hline
\end{tabular}

${ }^{a}$ The classification for this variable is not mutually exclusive.

${ }^{\mathrm{b}}$ In Virginia, a small business is defined as a company with fewer than 250 employees. 
Table 3: Characteristics of State Hiring Credits, 1969-June, 2012

\begin{tabular}{|c|c|c|c|}
\hline \multicolumn{1}{|c|}{ Type of Credit } & Count & Type of Credit & Count \\
\hline Basis for providing benefits $^{\mathbf{a}}$ & & Targeting & \\
\hline New jobs & 110 & Non-targeted & 75 \\
\hline New jobs only & 48 & Targeted & 72 \\
\hline New payroll & 66 & Industry targeting & 33 \\
\hline New payroll only & 20 & Manufacturing & 4 \\
\hline New investment & 29 & Targeting by type of business & 20 \\
\hline Other criteria & 28 & Large business & 6 \\
\hline Tax treatment & & Small business & 8 \\
\hline Tax credit is equal to tax owed & 21 & Headquarters & 6 \\
\hline Carry-forward is allowed & 67 & Targeting by type of worker ${ }^{\text {a }}$ & 24 \\
\hline Refundable (the whole value of \\
the credit is paid even if it is \\
higher than the value of the tax \\
owed)
\end{tabular}

\footnotetext{
${ }^{\mathrm{a}}$ The classification for this variable is not mutually exclusive.
} 
Table 4: Total Number of Changes States with Specific Types of Credits, 1990-2011

\begin{tabular}{|c|c|c|c|c|c|c|c|c|c|c|c|c|c|c|c|c|c|c|c|c|c|c|}
\hline Year & 1990 & 1991 & 1992 & 1993 & 1994 & 1995 & 1996 & 1997 & 1998 & 1999 & 2000 & 2001 & 2002 & 2003 & 2004 & 2005 & 2006 & 2007 & 2008 & 2009 & 2010 & 2011 \\
\hline Any credit & 0 & 2 & 0 & 3 & 4 & 8 & 3 & 2 & 2 & 0 & 0 & 0 & 2 & 0 & 0 & 0 & 0 & 0 & 0 & 2 & 0 & 0 \\
\hline
\end{tabular}




\begin{tabular}{|c|c|c|c|c|c|c|c|c|c|c|c|c|c|c|c|c|c|c|c|c|c|c|}
\hline Jobs & 0 & 2 & 0 & 3 & 4 & 7 & 3 & 1 & 2 & 1 & 0 & 0 & 1 & 1 & 0 & 0 & 1 & 1 & 0 & 2 & 0 & 0 \\
\hline Payroll & 0 & 0 & 1 & 1 & 2 & 5 & 3 & 2 & 2 & 1 & 0 & 0 & 0 & 1 & 1 & 1 & 2 & 1 & 0 & 3 & 1 & 2 \\
\hline Investment & 0 & 2 & 1 & 0 & 0 & 3 & 4 & 2 & 0 & 0 & 1 & 0 & 1 & 1 & 0 & 0 & 0 & 1 & 0 & 0 & 1 & 0 \\
\hline Full time & 0 & 0 & 2 & 1 & 2 & 7 & 3 & 3 & 2 & 1 & 0 & 0 & 0 & 1 & 0 & 1 & 0 & 0 & 0 & 3 & 1 & 0 \\
\hline Full time equiv. & 0 & 1 & 0 & 2 & 1 & 0 & 2 & 1 & 1 & 0 & 0 & 0 & 1 & 0 & 0 & 1 & 0 & 2 & 1 & 1 & 2 & 1 \\
\hline Part time & 0 & 0 & 0 & 0 & 0 & 0 & 0 & 0 & 0 & 0 & 0 & 0 & 1 & 0 & 0 & 0 & 2 & 0 & 0 & 0 & 0 & 0 \\
\hline Not specified & 0 & 1 & 0 & 0 & 2 & 1 & 0 & 2 & 1 & 1 & 0 & 0 & 1 & 0 & 0 & 0 & 1 & 0 & 0 & 1 & 0 & 0 \\
\hline Equal to tax owed & 0 & 0 & 0 & 2 & 0 & 2 & 0 & 1 & 2 & 0 & 0 & 0 & 0 & 1 & 0 & 0 & 1 & 0 & 1 & 1 & 0 & 1 \\
\hline Carry-forward & 0 & 0 & 0 & 1 & 1 & 6 & 2 & 1 & 3 & 2 & 0 & 0 & 2 & 0 & 0 & 0 & 1 & 0 & 0 & 3 & 0 & 0 \\
\hline Refundable & 0 & 0 & 0 & 1 & 1 & 3 & 0 & 0 & 0 & 0 & 0 & 0 & 0 & 0 & 1 & 2 & 0 & 1 & 0 & 0 & 2 & 2 \\
\hline Not specified & 0 & 2 & 2 & 0 & 4 & 1 & 3 & 2 & 0 & 0 & 1 & 0 & 1 & 1 & 0 & 2 & 1 & 0 & 1 & 3 & 2 & 2 \\
\hline $\begin{array}{c}\text { Wage requirement } \\
\text { No wage }\end{array}$ & 0 & 1 & 0 & 2 & 4 & 7 & 4 & 2 & 4 & 0 & 2 & 1 & 1 & 0 & 1 & 1 & 1 & 1 & 0 & 3 & 1 & 0 \\
\hline Recapture & 0 & 1 & 1 & 3 & 3 & 6 & 4 & 2 & 2 & 0 & 0 & 0 & 1 & 0 & 0 & 2 & 0 & 1 & 0 & 1 & 2 & 0 \\
\hline No recapture & 0 & 1 & 0 & 0 & 2 & 4 & 1 & 3 & 1 & 2 & 0 & 0 & 1 & 1 & 0 & 0 & 2 & 0 & 0 & 3 & 1 & 1 \\
\hline Industry & 0 & 1 & 1 & 0 & 1 & 5 & 1 & 2 & 0 & 1 & 0 & 0 & 2 & 0 & 0 & 0 & 0 & 1 & 0 & 1 & 0 & 1 \\
\hline Manufacturing & 0 & 0 & 1 & 0 & 0 & 0 & 0 & 0 & 0 & 0 & 0 & 0 & 0 & 0 & 0 & 0 & 0 & 0 & 0 & 0 & 1 & 0 \\
\hline No targeting & 0 & 1 & 0 & 3 & 3 & 5 & 2 & 2 & 3 & 1 & 0 & 1 & 0 & 2 & 0 & 1 & 0 & 0 & 0 & 2 & 1 & 0 \\
\hline Unemployed & 0 & 0 & 1 & 0 & 0 & 0 & 0 & 1 & 0 & 0 & 0 & 0 & 0 & 0 & 0 & 0 & 0 & 0 & 0 & 0 & 3 & 1 \\
\hline Welfare recipient & 0 & 0 & 1 & 0 & 1 & 2 & 0 & 1 & 2 & 1 & 0 & 0 & 0 & 0 & 0 & 0 & 0 & 0 & 0 & 0 & 0 & 0 \\
\hline Disabled & 0 & 0 & 0 & 0 & 0 & 1 & 0 & 2 & 0 & 1 & 0 & 0 & 0 & 1 & 0 & 0 & 2 & 0 & 0 & 0 & 1 & 0 \\
\hline No targeting & 0 & 2 & 1 & 3 & 4 & 8 & 3 & 2 & 2 & 0 & 0 & 0 & 2 & 0 & 0 & 0 & 0 & 0 & 0 & 2 & 0 & 0 \\
\hline Temporary & 0 & 0 & 0 & 1 & 1 & 5 & 1 & 1 & 1 & 0 & 1 & 1 & 2 & 1 & 1 & 3 & 3 & 0 & 2 & 0 & 6 & 3 \\
\hline Permanent & 0 & 2 & 1 & 3 & 3 & 7 & 4 & 2 & 2 & 0 & 0 & 0 & 1 & 2 & 0 & 1 & 1 & 0 & 0 & 2 & 0 & 2 \\
\hline Undeterminable & 0 & 0 & 0 & 1 & 1 & 0 & 0 & 0 & 0 & 0 & 0 & 0 & 0 & 0 & 0 & 0 & 0 & 0 & 0 & 0 & 0 & 0 \\
\hline
\end{tabular}


Table 5: Estimated Effects of State Hiring Credits on Employment, Credit Dummy Variables Specifications, First Differences, 1995-2011

\begin{tabular}{|c|c|c|c|c|c|c|c|c|c|}
\hline Credit Variable(s) & Contemp. & +4 Lags & +8 Lags & +12 Lags & Credit Variable(s) & Contemp. & +4 Lags & +8 Lags & +12 Lags \\
\hline Credit & $\begin{array}{c}-0.0022 \\
(0.0017) \\
\end{array}$ & $\begin{array}{c}-0.0005 \\
(0.0012) \\
\end{array}$ & $\begin{array}{c}-0.0007 \\
(0.0019) \\
\end{array}$ & $\begin{array}{c}0.0001 \\
(0.0030) \\
\end{array}$ & Wage Requirement & $\begin{array}{c}-0.0008 \\
(0.0012)\end{array}$ & $\begin{array}{c}-0.0004 \\
(0.0011)\end{array}$ & $\begin{array}{c}-0.0002 \\
(0.0018)\end{array}$ & $\begin{array}{c}0.0001 \\
(0.0025)\end{array}$ \\
\hline Jobs & $\begin{array}{l}-0.0024 \\
(0.0017)\end{array}$ & $\begin{array}{c}-0.0019 \\
(0.0013)\end{array}$ & $\begin{array}{l}-0.0026 \\
(0.0020)\end{array}$ & $\begin{array}{l}-0.0016 \\
(0.0027)\end{array}$ & No Wage Requirement & $\begin{array}{c}-0.0008 \\
(0.0007) \\
\end{array}$ & $\begin{array}{c}-0.0019 \\
(0.0011) \\
\end{array}$ & $\begin{array}{c}-0.0036 \\
(0.0014) \\
\end{array}$ & $\begin{array}{c}-0.0031 \\
(0.0027) \\
\end{array}$ \\
\hline Payroll & $\begin{array}{l}-0.0009 \\
(0.0012)\end{array}$ & $\begin{array}{c}0.0001 \\
(0.0011)\end{array}$ & $\begin{array}{c}0.0008 \\
(0.0019)\end{array}$ & $\begin{array}{c}0.0000 \\
(0.0022)\end{array}$ & Recapture & $\begin{array}{c}-0.0001 \\
(0.0018)\end{array}$ & $\begin{array}{c}0.0022 \\
(0.0015)\end{array}$ & $\begin{array}{c}0.0034 \\
(0.0020)\end{array}$ & $\begin{array}{c}0.0042 \\
(0.0030)\end{array}$ \\
\hline Investment & $\begin{array}{c}0.0017 \\
(0.0015)\end{array}$ & $\begin{array}{c}0.0012 \\
(0.0017)\end{array}$ & $\begin{array}{c}0.0006 \\
(0.0025)\end{array}$ & $\begin{array}{c}0.0012 \\
(0.0035)\end{array}$ & No Recapture & $\begin{array}{c}0.0004 \\
(0.0010) \\
\end{array}$ & $\begin{array}{c}-0.0005 \\
(0.0009) \\
\end{array}$ & $\begin{array}{c}-0.0012 \\
(0.0015) \\
\end{array}$ & $\begin{array}{c}0.0001 \\
(0.0019) \\
\end{array}$ \\
\hline Others & $\begin{array}{c}-0.0002 \\
(0.0013) \\
\end{array}$ & $\begin{array}{c}0.0001 \\
(0.0017) \\
\end{array}$ & $\begin{array}{c}0.0000 \\
(0.0024) \\
\end{array}$ & $\begin{array}{l}-0.0010 \\
(0.0036) \\
\end{array}$ & Industry & $\begin{array}{c}0.0000 \\
(0.0012)\end{array}$ & $\begin{array}{l}-0.0020 \\
(0.0017)\end{array}$ & $\begin{array}{l}-0.0007 \\
(0.0026)\end{array}$ & $\begin{array}{c}0.0002 \\
(0.0031)\end{array}$ \\
\hline Full Time & $\begin{array}{l}-0.0005 \\
(0.0015)\end{array}$ & $\begin{array}{c}-0.0002 \\
(0.0013)\end{array}$ & $\begin{array}{l}-0.0001 \\
(0.0022)\end{array}$ & $\begin{array}{c}0.0001 \\
(0.0030)\end{array}$ & Manufacturing & & $\begin{array}{l}-0.0201 \\
(0.0009)\end{array}$ & $\begin{array}{l}-0.0146 \\
(0.0015)\end{array}$ & $\begin{array}{l}-0.0267 \\
(0.0019)\end{array}$ \\
\hline Full Time Equiv. & $\begin{array}{l}-0.0036 \\
(0.0012)\end{array}$ & $\begin{array}{c}-0.0024 \\
(0.0013)\end{array}$ & $\begin{array}{c}-0.0018 \\
(0.0023)\end{array}$ & $\begin{array}{c}-0.0049 \\
(0.0031)\end{array}$ & No Targeting & $\begin{array}{c}-0.0025 \\
(0.0018) \\
\end{array}$ & $\begin{array}{c}-0.0013 \\
(0.0015) \\
\end{array}$ & $\begin{array}{c}-0.0016 \\
(0.0020) \\
\end{array}$ & $\begin{array}{c}-0.0022 \\
(0.0034) \\
\end{array}$ \\
\hline Part Time & $\begin{array}{l}-0.0020 \\
(0.0016)\end{array}$ & $\begin{array}{l}-0.0029 \\
(0.0012)\end{array}$ & $\begin{array}{l}-0.0039 \\
(0.0022)\end{array}$ & $\begin{array}{l}-0.0052 \\
(0.0045)\end{array}$ & Unemployed & $\begin{array}{c}0.0026 \\
(0.0021)\end{array}$ & $\begin{array}{c}0.0044 \\
(0.0017)\end{array}$ & $\begin{array}{c}0.0036 \\
(0.0022)\end{array}$ & $\begin{array}{c}0.0028 \\
(0.0045)\end{array}$ \\
\hline Not Specified & $\begin{array}{c}-0.0014 \\
(0.0007) \\
\end{array}$ & $\begin{array}{c}-0.0017 \\
(0.0012) \\
\end{array}$ & $\begin{array}{c}-0.0031 \\
(0.0020) \\
\end{array}$ & $\begin{array}{c}-0.0057 \\
(0.0038) \\
\end{array}$ & Welfare recipient & $\begin{array}{c}0.0024 \\
(0.0020)\end{array}$ & $\begin{array}{c}-0.0002 \\
(0.0024)\end{array}$ & $\begin{array}{c}-0.0004 \\
(0.0039)\end{array}$ & $\begin{array}{l}-0.0011 \\
(0.0050)\end{array}$ \\
\hline Equal to tax owed & $\begin{array}{c}-0.0004 \\
(0.0020)\end{array}$ & $\begin{array}{c}0.0013 \\
(0.0032)\end{array}$ & $\begin{array}{c}0.0014 \\
(0.0039)\end{array}$ & $\begin{array}{c}-0.0011 \\
(0.0066)\end{array}$ & Disabled & $\begin{array}{c}-0.0022 \\
(0.0021)\end{array}$ & $\begin{array}{c}-0.0011 \\
(0.0016)\end{array}$ & $\begin{array}{c}0.0012 \\
(0.0028)\end{array}$ & $\begin{array}{c}0.0010 \\
(0.0047)\end{array}$ \\
\hline Carry-forward & $\begin{array}{l}-0.0020 \\
(0.0016)\end{array}$ & $\begin{array}{l}-0.0005 \\
(0.0013)\end{array}$ & $\begin{array}{l}-0.0010 \\
(0.0019)\end{array}$ & $\begin{array}{l}-0.0007 \\
(0.0027)\end{array}$ & No Targeting & $\begin{array}{l}-0.0025 \\
(0.0017) \\
\end{array}$ & $\begin{array}{c}-0.0004 \\
(0.0013) \\
\end{array}$ & $\begin{array}{l}-0.0005 \\
(0.0020) \\
\end{array}$ & $\begin{array}{c}0.0004 \\
(0.0033) \\
\end{array}$ \\
\hline Refundable & $\begin{array}{c}0.0017 \\
(0.0015)\end{array}$ & $\begin{array}{c}0.0012 \\
(0.0018)\end{array}$ & $\begin{array}{c}0.0039 \\
(0.0021)\end{array}$ & $\begin{array}{c}0.0044 \\
(0.0025)\end{array}$ & Temporary & $\begin{array}{l}-0.0008 \\
(0.0012)\end{array}$ & $\begin{array}{c}-0.0012 \\
(0.0010)\end{array}$ & $\begin{array}{c}-0.0003 \\
(0.0013)\end{array}$ & $\begin{array}{c}-0.0008 \\
(0.0024)\end{array}$ \\
\hline Not Specified & $\begin{array}{c}0.0003 \\
(0.0013) \\
\end{array}$ & $\begin{array}{c}-0.0003 \\
(0.0023) \\
\end{array}$ & $\begin{array}{c}-0.0006 \\
(0.0030) \\
\end{array}$ & $\begin{array}{l}-0.0010 \\
(0.0037) \\
\end{array}$ & Permanent & $\begin{array}{l}-0.0007 \\
(0.0009) \\
\end{array}$ & $\begin{array}{c}0.0001 \\
(0.0011) \\
\end{array}$ & $\begin{array}{c}0.0009 \\
(0.0016) \\
\end{array}$ & $\begin{array}{c}0.0013 \\
(0.0025) \\
\end{array}$ \\
\hline
\end{tabular}

The dependent variable is the first difference of the log of QCEW employment. The specification includes the first difference of the job credit dummy or dummies, and 12 lags of these first differences. In addition to the contemporaneous effect, the cumulative effects through 4, 8, and 12 lags are reported. Each panel reports a different specification. The first just includes a single dummy variable for whether there is a credit, the second includes dummy variables for whether there is a credit with each of the four possible bases for benefits, etc. The specification also includes: the contemporaneous value and 12 lags of the first difference of the state-specific shock variable (in logs); interactions of the first difference of the shock variable interacted with state dummy variables; the contemporaneous value and 12 lags of the first difference of the log of the minimum wage prevailing in the state; the contemporaneous value and 12 lags of the first difference of the control for extended UI benefits; a dummy variable for the political party of the Governor (measured annually); dummy variables for each month in the sample; and interactions between calendar month dummy variables and state dummy variables. The cyclical control is constructed using 1990 as the baseline year. The data are monthly. There are 10,150 observations. Standard errors, reported in parentheses, are clustered at the state level. 
Table 6: Estimated Effects of State Hiring Credits on Employment, Restricting Effects of Hiring Credits to Quadratic Specification, First Differences, 1995-2011

\begin{tabular}{|c|c|c|c|c|c|}
\hline Credit Variable(s) & Linear & Quadratic & Credit Variable(s) & Linear & Quadratic \\
\hline Credit & $\begin{array}{c}-0.0031 \\
(0.0034) \\
\end{array}$ & $\begin{array}{c}0.0033 \\
(0.0030) \\
\end{array}$ & Wage Requirement & $\begin{array}{l}-0.0014 \\
(0.0026)\end{array}$ & $\begin{array}{c}0.0009 \\
(0.0022)\end{array}$ \\
\hline Jobs & $\begin{array}{c}-0.0060 \\
(0.0035)\end{array}$ & $\begin{array}{c}0.0043 \\
(0.0029)\end{array}$ & No Wage Requirement & $\begin{array}{c}-0.0069 \\
(0.0030) \\
\end{array}$ & $\begin{array}{c}0.0049 \\
(0.0034) \\
\end{array}$ \\
\hline Payroll & $\begin{array}{l}-0.0006 \\
(0.0029)\end{array}$ & $\begin{array}{c}0.0000 \\
(0.0022)\end{array}$ & Recapture & $\begin{array}{c}0.0020 \\
(0.0032)\end{array}$ & $\begin{array}{c}0.0006 \\
(0.0030)\end{array}$ \\
\hline Investment & $\begin{array}{c}0.0057 \\
(0.0043)\end{array}$ & $\begin{array}{l}-0.0027 \\
(0.0038)\end{array}$ & No Recapture & $\begin{array}{l}-0.0009 \\
(0.0035) \\
\end{array}$ & $\begin{array}{c}0.0024 \\
(0.0033) \\
\end{array}$ \\
\hline Others & $\begin{array}{c}-0.0028 \\
(0.0045) \\
\end{array}$ & $\begin{array}{c}0.0021 \\
(0.0047) \\
\end{array}$ & Industry & $\begin{array}{l}-0.0027 \\
(0.0042)\end{array}$ & $\begin{array}{c}0.0030 \\
(0.0038)\end{array}$ \\
\hline Full Time & $\begin{array}{c}-0.0014 \\
(0.0036)\end{array}$ & $\begin{array}{c}0.0016 \\
(0.0026)\end{array}$ & Manufacturing & $\begin{array}{c}-0.0484 \\
(0.0029)\end{array}$ & $\begin{array}{c}0.0237 \\
(0.0023)\end{array}$ \\
\hline Full Time Equiv. & $\begin{array}{l}-0.0036 \\
(0.0040)\end{array}$ & $\begin{array}{c}0.0015 \\
(0.0045)\end{array}$ & No Targeting & $\begin{array}{c}-0.0043 \\
(0.0034) \\
\end{array}$ & $\begin{array}{c}0.0025 \\
(0.0028) \\
\end{array}$ \\
\hline Part Time & $\begin{array}{c}-0.0071 \\
(0.0035)\end{array}$ & $\begin{array}{c}0.0024 \\
(0.0046)\end{array}$ & Unemployed & $\begin{array}{c}0.0141 \\
(0.0059)\end{array}$ & $\begin{array}{c}-0.0164 \\
(0.0071)\end{array}$ \\
\hline Not Specified & $\begin{array}{c}-0.0020 \\
(0.0038) \\
\end{array}$ & $\begin{array}{c}0.0006 \\
(0.0041) \\
\end{array}$ & Welfare recipient & $\begin{array}{c}-0.0013 \\
(0.0063)\end{array}$ & $\begin{array}{c}-0.0001 \\
(0.0044)\end{array}$ \\
\hline Equal to tax owed & $\begin{array}{c}0.0078 \\
(0.0052)\end{array}$ & $\begin{array}{c}-0.0089 \\
(0.0048)\end{array}$ & Disabled & $\begin{array}{l}-0.0039 \\
(0.0022)\end{array}$ & $\begin{array}{c}0.0054 \\
(0.0027)\end{array}$ \\
\hline Carry-forward & $\begin{array}{l}-0.0035 \\
(0.0028)\end{array}$ & $\begin{array}{c}0.0037 \\
(0.0023)\end{array}$ & No Targeting & $\begin{array}{l}-0.0028 \\
(0.0035)\end{array}$ & $\begin{array}{c}0.0032 \\
(0.0030)\end{array}$ \\
\hline Refundable & $\begin{array}{c}0.0048 \\
(0.0033)\end{array}$ & $\begin{array}{l}-0.0031 \\
(0.0038)\end{array}$ & Temporary & $\begin{array}{l}-0.0005 \\
(0.0025)\end{array}$ & $\begin{array}{c}0.0002 \\
(0.0023)\end{array}$ \\
\hline Not Specified & $\begin{array}{c}0.0018 \\
(0.0055)\end{array}$ & $\begin{array}{c}0.0003 \\
(0.0040)\end{array}$ & Permanent & $\begin{array}{c}-0.0032 \\
(0.0031)\end{array}$ & $\begin{array}{c}0.0029 \\
(0.0031)\end{array}$ \\
\hline
\end{tabular}

Notes from Table 5 apply. However, rather than estimated unrestricted coefficients of the contemporaneous and lagged hiring credit variables, the effects are restricted to lie along a quadratic function, as described in the text. 
Table 7: Estimated Effects of State Hiring Credits on Employment, Credit Dummy Variables Specifications, First Differences, 1991-2011

\begin{tabular}{|c|c|c|c|c|c|c|c|c|c|}
\hline Credit Variable(s) & Contemp. & +4 Lags & +8 Lags & +12 Lags & Credit Variable(s) & Contemp. & +4 Lags & +8 Lags & +12 Lags \\
\hline Credit & $\begin{array}{l}-0.0005 \\
(0.0010)\end{array}$ & $\begin{array}{l}-0.0003 \\
(0.0009)\end{array}$ & $\begin{array}{l}-0.0008 \\
(0.0012)\end{array}$ & $\begin{array}{c}0.0006 \\
(0.0019)\end{array}$ & Wage Requirement & $\begin{array}{l}-0.0003 \\
(0.0010)\end{array}$ & $\begin{array}{l}-0.0007 \\
(0.0009)\end{array}$ & $\begin{array}{l}-0.0007 \\
(0.0015)\end{array}$ & $\begin{array}{c}0.0000 \\
(0.0020)\end{array}$ \\
\hline Jobs & $\begin{array}{l}-0.0006 \\
(0.0011)\end{array}$ & $\begin{array}{l}-0.0011 \\
(0.0011)\end{array}$ & $\begin{array}{l}-0.0023 \\
(0.0016)\end{array}$ & $\begin{array}{c}-0.0006 \\
(0.0020)\end{array}$ & No Wage Requirement & $\begin{array}{l}-0.0002 \\
(0.0007)\end{array}$ & $\begin{array}{l}-0.0013 \\
(0.0012)\end{array}$ & $\begin{array}{l}-0.0027 \\
(0.0012)\end{array}$ & $\begin{array}{l}-0.0025 \\
(0.0025)\end{array}$ \\
\hline Payroll & $\begin{array}{l}-0.0004 \\
(0.0010)\end{array}$ & $\begin{array}{c}0.0006 \\
(0.0009)\end{array}$ & $\begin{array}{c}0.0015 \\
(0.0017)\end{array}$ & $\begin{array}{c}0.0008 \\
(0.0018)\end{array}$ & Recapture & $\begin{array}{c}0.0007 \\
(0.0012)\end{array}$ & $\begin{array}{c}0.0010 \\
(0.0012)\end{array}$ & $\begin{array}{c}0.0019 \\
(0.0014)\end{array}$ & $\begin{array}{c}0.0028 \\
(0.0021)\end{array}$ \\
\hline Investment & $\begin{array}{c}0.0011 \\
(0.0013)\end{array}$ & $\begin{array}{c}0.0006 \\
(0.0018)\end{array}$ & $\begin{array}{c}0.0008 \\
(0.0023)\end{array}$ & $\begin{array}{c}0.0009 \\
(0.0030)\end{array}$ & No Recapture & $\begin{array}{c}0.0004 \\
(0.0009) \\
\end{array}$ & $\begin{array}{r}0.0000 \\
(0.0010) \\
\end{array}$ & $\begin{array}{l}-0.0001 \\
(0.0013)\end{array}$ & $\begin{array}{c}0.0013 \\
(0.0017) \\
\end{array}$ \\
\hline Others & $\begin{array}{l}-0.0003 \\
(0.0011)\end{array}$ & $\begin{array}{l}-0.0006 \\
(0.0012)\end{array}$ & $\begin{array}{c}-0.0007 \\
(0.0019)\end{array}$ & $\begin{array}{c}-0.0011 \\
(0.0023)\end{array}$ & Industry & $\begin{array}{c}0.0004 \\
(0.0010)\end{array}$ & $\begin{array}{l}-0.0018 \\
(0.0014)\end{array}$ & $\begin{array}{l}-0.0005 \\
(0.0020)\end{array}$ & $\begin{array}{c}-0.0001 \\
(0.0025)\end{array}$ \\
\hline Full Time & $\begin{array}{c}-0.0001 \\
(0.0011)\end{array}$ & $\begin{array}{c}0.0001 \\
(0.0010)\end{array}$ & $\begin{array}{c}0.0006 \\
(0.0016)\end{array}$ & $\begin{array}{c}0.0012 \\
(0.0021)\end{array}$ & Manufacturing & $\begin{array}{l}-0.0026 \\
(0.0064)\end{array}$ & $\begin{array}{l}-0.0100 \\
(0.0081)\end{array}$ & $\begin{array}{l}-0.0037 \\
(0.0054)\end{array}$ & $\begin{array}{c}-0.0088 \\
(0.0094)\end{array}$ \\
\hline Full Time Equiv. & $\begin{array}{l}-0.0018 \\
(0.0010)\end{array}$ & $\begin{array}{l}-0.0028 \\
(0.0013)\end{array}$ & $\begin{array}{l}-0.0030 \\
(0.0023)\end{array}$ & $\begin{array}{l}-0.0048 \\
(0.0029)\end{array}$ & No Targeting & $\begin{array}{l}-0.0012 \\
(0.0012)\end{array}$ & $\begin{array}{l}-0.0007 \\
(0.0010)\end{array}$ & $\begin{array}{c}-0.0014 \\
(0.0014)\end{array}$ & $\begin{array}{c}-0.0008 \\
(0.0022)\end{array}$ \\
\hline Part Time & $\begin{array}{c}-0.0024 \\
(0.0019)\end{array}$ & $\begin{array}{c}-0.0034 \\
(0.0011)\end{array}$ & $\begin{array}{l}-0.0046 \\
(0.0011)\end{array}$ & $\begin{array}{c}-0.0061 \\
(0.0024)\end{array}$ & Unemployed & $\begin{array}{c}0.0019 \\
(0.0021)\end{array}$ & $\begin{array}{c}0.0040 \\
(0.0018)\end{array}$ & $\begin{array}{c}0.0029 \\
(0.0022)\end{array}$ & $\begin{array}{c}0.0026 \\
(0.0038)\end{array}$ \\
\hline Not Specified & $\begin{array}{l}-0.0010 \\
(0.0007)\end{array}$ & $\begin{array}{c}0.0003 \\
(0.0015) \\
\end{array}$ & $\begin{array}{c}0.0002 \\
(0.0026) \\
\end{array}$ & $\begin{array}{l}-0.0015 \\
(0.0035)\end{array}$ & Welfare recipient & $\begin{array}{c}0.0005 \\
(0.0017)\end{array}$ & $\begin{array}{c}0.0005 \\
(0.0022)\end{array}$ & $\begin{array}{c}0.0012 \\
(0.0035)\end{array}$ & $\begin{array}{c}0.0008 \\
(0.0045)\end{array}$ \\
\hline Equal to tax owed & $\begin{array}{c}0.0005 \\
(0.0017)\end{array}$ & $\begin{array}{c}0.0003 \\
(0.0026)\end{array}$ & $\begin{array}{l}-0.0013 \\
(0.0034)\end{array}$ & $\begin{array}{c}-0.0024 \\
(0.0050)\end{array}$ & Disabled & $\begin{array}{c}-0.0014 \\
(0.0019)\end{array}$ & $\begin{array}{c}0.0000 \\
(0.0016)\end{array}$ & $\begin{array}{c}0.0022 \\
(0.0029)\end{array}$ & $\begin{array}{c}0.0025 \\
(0.0044)\end{array}$ \\
\hline Carry-forward & $\begin{array}{l}-0.0013 \\
(0.0012)\end{array}$ & $\begin{array}{c}0.0006 \\
(0.0012)\end{array}$ & $\begin{array}{c}0.0002 \\
(0.0018)\end{array}$ & $\begin{array}{c}0.0001 \\
(0.0024)\end{array}$ & No Targeting & $\begin{array}{l}-0.0007 \\
(0.0010)\end{array}$ & $\begin{array}{l}-0.0005 \\
(0.0009)\end{array}$ & $\begin{array}{l}-0.0009 \\
(0.0014)\end{array}$ & $\begin{array}{c}0.0006 \\
(0.0021) \\
\end{array}$ \\
\hline Refundable & $\begin{array}{c}0.0014 \\
(0.0012)\end{array}$ & $\begin{array}{c}0.0013 \\
(0.0014)\end{array}$ & $\begin{array}{c}0.0034 \\
(0.0020)\end{array}$ & $\begin{array}{c}0.0041 \\
(0.0022)\end{array}$ & Temporary & $\begin{array}{l}-0.0009 \\
(0.0011)\end{array}$ & $\begin{array}{l}-0.0013 \\
(0.0010)\end{array}$ & $\begin{array}{l}-0.0005 \\
(0.0011)\end{array}$ & $\begin{array}{c}-0.0008 \\
(0.0021)\end{array}$ \\
\hline Not Specified & $\begin{array}{c}0.0005 \\
(0.0010)\end{array}$ & $\begin{array}{l}-0.0008 \\
(0.0017)\end{array}$ & $\begin{array}{c}0.0004 \\
(0.0020)\end{array}$ & $\begin{array}{c}0.0007 \\
(0.0025)\end{array}$ & Permanent & $\begin{array}{c}0.0004 \\
(0.0007)\end{array}$ & $\begin{array}{l}-0.0001 \\
(0.0009)\end{array}$ & $\begin{array}{c}0.0006 \\
(0.0014)\end{array}$ & $\begin{array}{c}0.0014 \\
(0.0018) \\
\end{array}$ \\
\hline
\end{tabular}

The dependent variable is the first difference of the log of QCEW employment. The specification includes the first difference of the job credit dummy or dummies, and 12 lags of this first difference. In addition to the contemporaneous effect, the cumulative effects through 4, 8, and 12 lags are reported. Each panel reports a different specification. The first just includes a single dummy variable for whether there is a credit, the second includes dummy variables for whether there is a credit with each of the four possible bases for benefits, etc. The specification also includes: the contemporaneous value and 12 lags of the first difference of the state-specific shock variable (in logs); interactions of the first difference of the shock variable interacted with state dummy variables; the contemporaneous value and 12 lags of the first difference of the log of the minimum wage prevailing in the state; dummy variable for the political party of the Governor (measured annually); dummy variables for each month in the sample; and interactions between calendar month dummy variables and state dummy variables. The UI benefits control is not included because the data do not extend back to the beginning of the sample period used in this table. The cyclical control is constructed using 1990 as the baseline year. The data are monthly. There are 12,550 observations. Standard errors, reported in parentheses, are clustered at the state level. 
Table 8: Estimated Effects of State Hiring Credits on Employment, Credit Dummy Variables Specifications, First Differences, with ARRA Spending and Housing Appreciation Controls, 2007-2011

\begin{tabular}{|c|c|c|c|c|c|c|c|c|c|}
\hline Credit Variable(s) & Contemp. & +4 Lags & +8 Lags & +12 Lags & Credit Variable(s) & Contemp. & +4 Lags & +8 Lags & +12 Lags \\
\hline ARRA variable & Contemp. & +6 Lags & +12 Lags & +24 Lags & & & & & \\
\hline ARRA & $\begin{array}{c}-0.0017 \\
(0.0014)\end{array}$ & $\begin{array}{c}0.0002 \\
(0.0023)\end{array}$ & $\begin{array}{c}-0.0001 \\
(0.0029) \\
\end{array}$ & $\begin{array}{c}0.0017 \\
(0.0037) \\
\end{array}$ & & & & & \\
\hline Credit & $\begin{array}{c}0.0011 \\
(0.0015)\end{array}$ & $\begin{array}{c}-0.0014 \\
(0.0023)\end{array}$ & $\begin{array}{c}-0.0067 \\
(0.0040)\end{array}$ & $\begin{array}{c}-0.0084 \\
(0.0049)\end{array}$ & Wage Requirement & $\begin{array}{l}-0.0007 \\
(0.0010)\end{array}$ & $\begin{array}{c}0.0023 \\
(0.0021)\end{array}$ & $\begin{array}{c}0.0033 \\
(0.0039)\end{array}$ & $\begin{array}{c}0.0026 \\
(0.0040)\end{array}$ \\
\hline Jobs & $\begin{array}{c}0.0016 \\
(0.0014)\end{array}$ & $\begin{array}{l}-0.0008 \\
(0.0025)\end{array}$ & $\begin{array}{l}-0.0035 \\
(0.0046)\end{array}$ & $\begin{array}{l}-0.0066 \\
(0.0045)\end{array}$ & No Wage Requirement & $\begin{array}{l}-0.0008 \\
(0.0024)\end{array}$ & $\begin{array}{l}-0.0050 \\
(0.0040)\end{array}$ & $\begin{array}{c}-0.0082 \\
(0.0057) \\
\end{array}$ & $\begin{array}{l}-0.0135 \\
(0.0104)\end{array}$ \\
\hline Payroll & $\begin{array}{l}-0.0009 \\
(0.0011)\end{array}$ & $\begin{array}{c}0.0005 \\
(0.0012)\end{array}$ & $\begin{array}{c}0.0008 \\
(0.0030)\end{array}$ & $\begin{array}{l}-0.0004 \\
(0.0024)\end{array}$ & Recapture & $\begin{array}{c}0.0033 \\
(0.0023)\end{array}$ & $\begin{array}{c}0.0057 \\
(0.0018)\end{array}$ & $\begin{array}{c}0.0064 \\
(0.0031)\end{array}$ & $\begin{array}{c}0.0082 \\
(0.0042)\end{array}$ \\
\hline Investment & $\begin{array}{c}0.0091 \\
(0.0012)\end{array}$ & $\begin{array}{c}0.0060 \\
(0.0024)\end{array}$ & $\begin{array}{c}0.0053 \\
(0.0058)\end{array}$ & $\begin{array}{c}0.0044 \\
(0.0043)\end{array}$ & No Recapture & $\begin{array}{c}0.0027 \\
(0.0014) \\
\end{array}$ & $\begin{array}{l}-0.0015 \\
(0.0020) \\
\end{array}$ & $\begin{array}{l}-0.0040 \\
(0.0028)\end{array}$ & $\begin{array}{l}-0.0049 \\
(0.0034)\end{array}$ \\
\hline Others & $\begin{array}{c}0.0007 \\
(0.0017) \\
\end{array}$ & $\begin{array}{l}-0.0034 \\
(0.0029) \\
\end{array}$ & $\begin{array}{l}-0.0059 \\
(0.0045) \\
\end{array}$ & $\begin{array}{l}-0.0076 \\
(0.0062) \\
\end{array}$ & Industry & $\begin{array}{c}0.0001 \\
(0.0012)\end{array}$ & $\begin{array}{l}-0.0042 \\
(0.0020)\end{array}$ & $\begin{array}{l}-0.0068 \\
(0.0029)\end{array}$ & $\begin{array}{c}-0.0094 \\
(0.0036)\end{array}$ \\
\hline Full Time & $\begin{array}{c}0.0014 \\
(0.0015)\end{array}$ & $\begin{array}{c}0.0004 \\
(0.0025)\end{array}$ & $\begin{array}{l}-0.0019 \\
(0.0038)\end{array}$ & $\begin{array}{l}-0.0018 \\
(0.0058)\end{array}$ & Manufacturing & $\begin{array}{l}-0.0011 \\
(0.0012)\end{array}$ & $\begin{array}{l}-0.0090 \\
(0.0028)\end{array}$ & $\begin{array}{l}-0.0091 \\
(0.0040)\end{array}$ & $\begin{array}{l}-0.0132 \\
(0.0049)\end{array}$ \\
\hline Full Time Equiv. & $\begin{array}{l}-0.0050 \\
(0.0015)\end{array}$ & $\begin{array}{l}-0.0076 \\
(0.0028)\end{array}$ & $\begin{array}{l}-0.0091 \\
(0.0054)\end{array}$ & $\begin{array}{l}-0.0177 \\
(0.0070)\end{array}$ & No Targeting & $\begin{array}{c}0.0019 \\
(0.0012) \\
\end{array}$ & $\begin{array}{c}0.0003 \\
(0.0023) \\
\end{array}$ & $\begin{array}{l}-0.0041 \\
(0.0034) \\
\end{array}$ & $\begin{array}{c}-0.0051 \\
(0.0040) \\
\end{array}$ \\
\hline Part Time & $\ldots$ & $\ldots$ & $\begin{array}{c}0.0006 \\
(0.0017)\end{array}$ & $\begin{array}{c}0.0092 \\
(0.0034)\end{array}$ & Unemployed & $\begin{array}{c}0.0061 \\
(0.0014)\end{array}$ & $\begin{array}{c}0.0084 \\
(0.0021)\end{array}$ & $\begin{array}{c}0.0082 \\
(0.0033)\end{array}$ & $\begin{array}{c}0.0116 \\
(0.0045)\end{array}$ \\
\hline Not Specified & $\begin{array}{c}0.0009 \\
(0.0010) \\
\end{array}$ & $\begin{array}{l}-0.0027 \\
(0.0026) \\
\end{array}$ & $\begin{array}{l}-0.0049 \\
(0.0036) \\
\end{array}$ & $\begin{array}{l}-0.0055 \\
(0.0050) \\
\end{array}$ & Welfare recipient & .. & $\cdots$ & $\cdots$ & ... \\
\hline Equal to tax owed & $\begin{array}{l}-0.0049 \\
(0.0012)\end{array}$ & $\begin{array}{l}-0.0072 \\
(0.0056)\end{array}$ & $\begin{array}{l}-0.0115 \\
(0.0070)\end{array}$ & $\begin{array}{l}-0.0247 \\
(0.0137)\end{array}$ & Disabled & $\begin{array}{l}-0.0094 \\
(0.0019)\end{array}$ & $\begin{array}{c}0.0015 \\
(0.0033)\end{array}$ & $\begin{array}{c}0.0034 \\
(0.0024)\end{array}$ & $\begin{array}{c}0.0036 \\
(0.0074)\end{array}$ \\
\hline Carry-forward & $\begin{array}{c}0.0012 \\
(0.0010)\end{array}$ & $\begin{array}{l}-0.0009 \\
(0.0046)\end{array}$ & $\begin{array}{l}-0.0049 \\
(0.0056)\end{array}$ & $\begin{array}{l}-0.0051 \\
(0.0086)\end{array}$ & No Targeting & $\begin{array}{c}0.0012 \\
(0.0016) \\
\end{array}$ & $\begin{array}{c}-0.0014 \\
(0.0023) \\
\end{array}$ & $\begin{array}{l}-0.0069 \\
(0.0041) \\
\end{array}$ & $\begin{array}{c}-0.0084 \\
(0.0051) \\
\end{array}$ \\
\hline Refundable & $\begin{array}{c}0.0012 \\
(0.0030)\end{array}$ & $\begin{array}{c}0.0027 \\
(0.0037)\end{array}$ & $\begin{array}{c}0.0055 \\
(0.0042)\end{array}$ & $\begin{array}{c}0.0017 \\
(0.0061)\end{array}$ & Temporary & $\begin{array}{l}-0.0010 \\
(0.0020)\end{array}$ & $\begin{array}{l}-0.0032 \\
(0.0032)\end{array}$ & $\begin{array}{l}-0.0032 \\
(0.0048)\end{array}$ & $\begin{array}{l}-0.0049 \\
(0.0080)\end{array}$ \\
\hline Not Specified & $\begin{array}{c}0.0028 \\
(0.0014)\end{array}$ & $\begin{array}{c}0.0003 \\
(0.0029)\end{array}$ & $\begin{array}{c}-0.0014 \\
(0.0040)\end{array}$ & $\begin{array}{l}-0.0018 \\
(0.0048)\end{array}$ & Permanent & $\begin{array}{c}0.0009 \\
(0.0009) \\
\end{array}$ & $\begin{array}{l}-0.0030 \\
(0.0019)\end{array}$ & $\begin{array}{l}-0.0064 \\
(0.0026)\end{array}$ & $\begin{array}{l}-0.0081 \\
(0.0035)\end{array}$ \\
\hline
\end{tabular}

The dependent variable is the first difference of the log of QCEW employment. The specification includes the first difference of the job credit dummy or dummies, and 12 lags of this first difference. In addition to the contemporaneous effect, the cumulative effects through 4, 8 , and 12 lags are reported. Each panel reports a different specification. The first just includes a single dummy variable for whether there is a credit, the second includes dummy variables for whether there is a credit with each of the four possible bases for benefits, etc. The specification also includes: the contemporaneous value and 12 lags of the first difference of the state-specific shock variable (in logs); interactions of the first difference of the shock variable interacted with state dummy variables; the contemporaneous value and 12 lags of the first difference of the log of the minimum wage prevailing in the state; the contemporaneous value and 12 lags of the first difference of the control for extended UI benefits; dummy variable for the political party of the Governor (measured annually); dummy variables for each 
month in the sample; and interactions between calendar month dummy variables and state dummy variables. We add contemporaneous ARRA obligated spending, and 24 lags, in logs. Spending is entered in logs so zeros are replaced with ones in levels before taking logs. (Cumulative effects through six, 12, and 24 lags are reported.) We also add dummy variables for the quintiles of housing price appreciation for the 2000-2006 period interacted with calendar month dummy variables. We report estimates of the coefficients of ARRA spending only for the first specification; results were similar for the other models. The cyclical control is constructed using 2006 as the baseline year. The data are monthly. There are 2,950 observations. Standard errors, reported in parentheses, are clustered at the state level. 
Table 9: Estimated Effects of State Hiring Credits on Employment, with Interactions between Hiring Credit Variables and Recession Indicators, 1991-2011

\begin{tabular}{|lcccc|}
\hline Credit Variable(s) & Contemp. & +4 Lags & +8 Lags & +12 Lags \\
\hline Refundable: main effect & 0.0005 & -0.0001 & 0.0022 & 0.0025 \\
& $(0.0012)$ & $(0.0014)$ & $(0.0023)$ & $(0.0023)$ \\
Refundable: interaction & 0.0124 & 0.0177 & 0.0158 & 0.0189 \\
& $(0.0013)$ & $(0.0022)$ & $(0.0032)$ & $(0.0032)$ \\
Refundable: main effect & 0.0130 & 0.0176 & 0.0180 & 0.0214 \\
+ interaction & $(0.0004)$ & $(0.0015)$ & $(0.0015)$ & $(0.0028)$ \\
\hline Recapture: main effect & 0.0000 & 0.0009 & 0.0021 & 0.0036 \\
& $(0.0013)$ & $(0.0011)$ & $(0.0016)$ & $(0.0020)$ \\
Recapture: interaction & 0.0041 & 0.0010 & -0.0005 & -0.0040 \\
& $(0.0023)$ & $(0.0043)$ & $(0.0036)$ & $(0.0062)$ \\
Recapture: main effect & 0.0042 & 0.0019 & 0.0016 & -0.0004 \\
+ interaction & $(0.0019)$ & $(0.0042)$ & $(0.0033)$ & $(0.0060)$ \\
\hline Unemployed: main effect & 0.0015 & 0.0012 & 0.0010 & 0.0004 \\
& $(0.0028)$ & $(0.0027)$ & $(0.0024)$ & $(0.0043)$ \\
Unemployed: interaction & 0.0048 & 0.0111 & 0.0089 & 0.0097 \\
& $(0.0056)$ & $(0.0056)$ & $(0.0073)$ & $(0.0117)$ \\
Unemployed: main effect & 0.0063 & 0.0123 & 0.0100 & 0.0101 \\
+ interaction & $(0.0049)$ & $(0.0049)$ & $(0.0071)$ & $(0.0117)$ \\
\hline
\end{tabular}

Notes from Table 7 apply, and the specifications correspond to those in Table 7. However, we also add interactions between the hiring credit variables and indicators for recessions. The indicators for recessions are based on NBER dates, and a period one year from the end of each recession. The recession periods, therefore, are July 1990-March 1992, March 2001-November 2002, and December 2007-June 2010. These recession indicators are interacted with the contemporaneous value and all lags of the set of hiring credit variables included in each specification (e.g., equal to tax owed, carry-forward, refundable, and not specified, for the different credits based on tax treatment). For each specification reported, the contemporaneous and the cumulative lags of these interactions are reported, for the three specific types of hiring credits listed. 
Table 10: Estimated Effects of Lagged Employment Growth (and Political Control) on State Hiring Credits

\begin{tabular}{|c|c|c|c|c|c|c|c|c|c|c|c|c|c|}
\hline & & \multicolumn{4}{|c|}{ Credit with refundable benefit } & \multicolumn{4}{|c|}{ Credit with recapture provisions } & \multicolumn{4}{|c|}{ Credit targeting the unemployed } \\
\hline & & +6 lags & +12 lags & +24 lags & +36 lags & +6 lags & +12 lags & +24 lags & +36 lags & +6 lags & +12 lags & +24 lags & +36 lags \\
\hline \multirow{4}{*}{$1995-2011$} & Employment & -0.2863 & -0.4772 & -0.1946 & -0.4410 & -0.0122 & 0.1892 & -0.3422 & -0.5737 & -0.0676 & -0.0199 & -0.3924 & -0.8104 \\
\hline & growth & $(0.1934)$ & $(0.3293)$ & $(0.4013)$ & $(0.8017)$ & $(0.2446)$ & $(0.4088)$ & $(0.4818)$ & $(0.8462)$ & $(0.1195)$ & $(0.1109)$ & $(0.2817)$ & $(0.6484)$ \\
\hline & Party of & 0.0005 & -0.0005 & 0.0005 & 0.0008 & 0.0021 & 0.0007 & -0.0009 & 0.0010 & 0.0006 & -0.0005 & 0.0000 & -0.0009 \\
\hline & governor & $(0.0015)$ & $(0.0011)$ & $(0.0010)$ & $(0.0008)$ & $(0.0013)$ & $(0.0032)$ & $(0.0046)$ & $(0.0012)$ & $(0.0011)$ & $(0.0010)$ & $(0.0009)$ & $(0.0006)$ \\
\hline \multirow{3}{*}{ 1991-2011 } & Employment & -0.0335 & -0.0844 & 0.0623 & -0.0460 & -0.1286 & 0.2005 & -0.5671 & -0.9527 & -0.1004 & -0.0527 & -0.3461 & -0.7477 \\
\hline & growth & $(0.1923)$ & $(0.3283)$ & $(0.3654)$ & $(0.6710)$ & $(0.3526)$ & $(0.4959)$ & $(0.6264)$ & $(0.8685)$ & $(0.1192)$ & $(0.1227)$ & $(0.2219)$ & $(0.4375)$ \\
\hline & governor & $(0.0036)$ & $(0.0010)$ & $(0.0011)$ & $(0.0011)$ & $(0.0053)$ & $(0.0157)$ & $(0.0124)$ & $(0.0016)$ & $(0.0007)$ & $(0.0014)$ & $(0.0109)$ & $(0.0006)$ \\
\hline \multirow{4}{*}{$\begin{array}{l}2007-2011+ \\
\text { ARRA and } \\
\text { housing controls }\end{array}$} & Employment & -0.3199 & -0.4453 & 0.1659 & -0.7279 & 1.3224 & 1.3817 & 0.7327 & 0.6478 & 0.7452 & 0.3961 & 0.9642 & 0.6111 \\
\hline & growth & $(0.7038)$ & $(0.6713)$ & $(0.9462)$ & (1.3279) & $(1.3323)$ & (1.1107) & $(1.2408)$ & (1.0357) & $(0.8574)$ & $(0.8337)$ & (0.9399) & $(0.9973)$ \\
\hline & Party of & -0.0017 & 0.0356 & 0.0395 & 0.0071 & 0.0094 & -0.0447 & -0.0538 & 0.0039 & 0.0118 & 0.0291 & 0.0413 & -0.0020 \\
\hline & governor & $(0.0109)$ & $(0.0397)$ & $(0.0396)$ & $(0.0054)$ & $(0.0110)$ & $(0.0477)$ & $(0.0517)$ & $(0.0044)$ & $(0.0118)$ & $(0.0421)$ & $(0.0414)$ & $(0.0027)$ \\
\hline
\end{tabular}

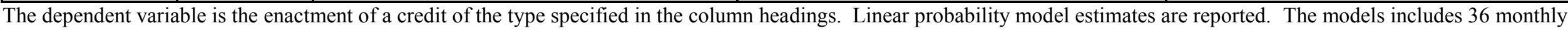

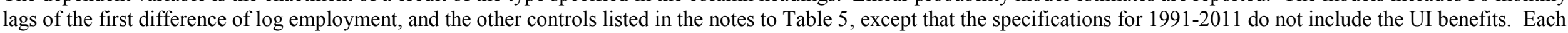

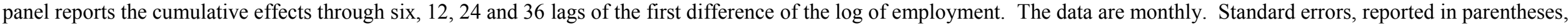
are clustered at the state level. 
Table 11: Multiple Testing Results for Key Hiring Credit Findings

\begin{tabular}{|c|c|c|c|c|c|c|c|c|c|c|c|c|}
\hline & & \multicolumn{3}{|c|}{ Credit with refundable benefit } & \multicolumn{4}{|c|}{ Credit with recapture provisions } & \multicolumn{4}{|c|}{ Credit targeting the unemployed } \\
\hline & & Contemp. +4 Lags & +8 Lags & +12 Lags & Contemp. & +4 Lags & +8 Lags & +12 Lags & Contemp. & +4 Lags & +8 Lags & +12 Lags \\
\hline 1995-2011 & $\begin{array}{l}\text { Reject single test, } \mathrm{p}=0.1 \\
\text { Reject multiple test, } \mathrm{p}=0.1 \\
\text { (Simes method) } \\
\text { Reject multiple test, } \mathrm{p}=0.1 \\
\text { (Sidak method) }\end{array}$ & & Yes & Yes & & & Yes & & & Yes & & \\
\hline 1991-2011 & $\begin{array}{l}\text { Reject single test, } \mathrm{p}=0.1 \\
\text { Reject multiple test, } \mathrm{p}=0.1 \\
\text { (Simes method) } \\
\text { Reject multiple test, } \mathrm{p}=0.1 \\
\text { (Sidak method) }\end{array}$ & & & Yes & & & & & & & Yes & \\
\hline $\begin{array}{l}2007-2011+ \\
\text { ARRA and } \\
\text { housing } \\
\text { controls }\end{array}$ & $\begin{array}{l}\text { Reject single test, } \mathrm{p}=0.1 \\
\text { Reject multiple test, } \mathrm{p}=0.1 \\
\text { (Simes method) } \\
\text { Reject multiple test, } \mathrm{p}=0.1 \\
\text { (Sidak method) }\end{array}$ & & & & & $\begin{array}{l}\text { Yes } \\
\text { Yes }\end{array}$ & Yes & Yes & $\begin{array}{l}\text { Yes } \\
\text { Yes } \\
\text { Yes }\end{array}$ & $\begin{array}{l}\text { Yes } \\
\text { Yes } \\
\text { Yes }\end{array}$ & $\begin{array}{l}\text { Yes } \\
\text { Yes }\end{array}$ & $\begin{array}{l}\text { Yes } \\
\text { Yes }\end{array}$ \\
\hline $\begin{array}{l}2007-2011+ \\
\text { ARRA and } \\
\text { housing } \\
\text { controls }\end{array}$ & $\begin{array}{l}\text { Reject single test, } \mathrm{p}=0.05 \\
\text { Reject multiple test, } \\
\mathrm{p}=0.05 \text { (Simes method) } \\
\text { Reject multiple test, } \\
\mathrm{p}=0.05 \text { (Sidak method) }\end{array}$ & & & & & $\begin{array}{l}\text { Yes } \\
\text { Yes }\end{array}$ & Yes & Yes & $\begin{array}{l}\text { Yes } \\
\text { Yes } \\
\text { Yes }\end{array}$ & $\begin{array}{l}\text { Yes } \\
\text { Yes } \\
\text { Yes }\end{array}$ & Yes & Yes \\
\hline
\end{tabular}

Calculations based on "multproc" code in Stata (Newson and The ALSPAC Study Team, 2003). We compute the corrected p-values based on the p-values for all of the estimated effects reported in Tables 5 (100 estimates), 7 (100 estimates), and 8 (96 estimates). 
Table 12: Estimated Effects of State Hiring Credits on Employment, Credit Dummy Variables Specifications, First Differences, 2007-2011, Quarterly Workforce Indicators Data

\begin{tabular}{|c|c|c|c|c|c|c|c|c|c|c|c|}
\hline Credit Variable(s) & Contemp. & $+1 \mathrm{Lag}$ & +2 Lags & +3 Lags & +4 Lags & Credit Variable(s) & Contemp. & +1 Lag & +2 Lags & +3 Lags & +4 Lags \\
\hline Credit & $\begin{array}{c}0.0005 \\
(0.0029)\end{array}$ & $\begin{array}{c}0.0008 \\
(0.0053)\end{array}$ & $\begin{array}{l}-0.0031 \\
(0.0059)\end{array}$ & $\begin{array}{l}-0.0027 \\
(0.0072)\end{array}$ & $\begin{array}{l}-0.0062 \\
(0.0083)\end{array}$ & Wage Requirement & $\begin{array}{c}0.0019 \\
(0.0023)\end{array}$ & $\begin{array}{c}0.0041 \\
(0.0032)\end{array}$ & $\begin{array}{c}0.0042 \\
(0.0035)\end{array}$ & $\begin{array}{c}0.0045 \\
(0.0039)\end{array}$ & $\begin{array}{c}0.0014 \\
(0.0053)\end{array}$ \\
\hline Jobs & $\begin{array}{c}0.0024 \\
(0.0050)\end{array}$ & $\begin{array}{c}0.0036 \\
(0.0080)\end{array}$ & $\begin{array}{c}-0.0012 \\
(0.0082)\end{array}$ & $\begin{array}{c}-0.0006 \\
(0.0096)\end{array}$ & $\begin{array}{c}-0.0007 \\
(0.0125)\end{array}$ & No Wage Requirement & $\begin{array}{l}-0.0031 \\
(0.0027)\end{array}$ & $\begin{array}{c}-0.0037 \\
(0.0047)\end{array}$ & $\begin{array}{c}-0.0070 \\
(0.0056)\end{array}$ & $\begin{array}{c}-0.0081 \\
(0.0070)\end{array}$ & $\begin{array}{c}-0.0177 \\
(0.0136)\end{array}$ \\
\hline Payroll & $\begin{array}{l}-0.0041 \\
(0.0058)\end{array}$ & $\begin{array}{l}-0.0055 \\
(0.0057)\end{array}$ & $\begin{array}{c}-0.0034 \\
(0.0065)\end{array}$ & $\begin{array}{c}-0.0034 \\
(0.0066)\end{array}$ & $\begin{array}{l}-0.0095 \\
(0.0088)\end{array}$ & Recapture & $\begin{array}{c}0.0086 \\
(0.0027)\end{array}$ & $\begin{array}{c}0.0067 \\
(0.0052)\end{array}$ & $\begin{array}{c}0.0117 \\
(0.0035)\end{array}$ & $\begin{array}{c}0.0158 \\
(0.0069)\end{array}$ & $\begin{array}{c}0.0113 \\
(0.0067)\end{array}$ \\
\hline Investment & $\ldots$ & $\begin{array}{l}-0.0097 \\
(0.0049)\end{array}$ & $\begin{array}{l}-0.0022 \\
(0.0054)\end{array}$ & $\begin{array}{l}-0.0111 \\
(0.0073)\end{array}$ & $\begin{array}{l}-0.0087 \\
(0.0103)\end{array}$ & No Recapture & $\begin{array}{c}0.0056 \\
(0.0034)\end{array}$ & $\begin{array}{c}0.0004 \\
(0.0029)\end{array}$ & $\begin{array}{l}-0.0007 \\
(0.0035)\end{array}$ & $\begin{array}{l}-0.0020 \\
(0.0038)\end{array}$ & $\begin{array}{l}-0.0037 \\
(0.0045)\end{array}$ \\
\hline Others & $\begin{array}{c}0.0039 \\
(0.0030)\end{array}$ & $\begin{array}{c}-0.0054 \\
(0.0037)\end{array}$ & $\begin{array}{c}-0.0089 \\
(0.0056)\end{array}$ & $\begin{array}{c}-0.0064 \\
(0.0074)\end{array}$ & $\begin{array}{l}-0.0076 \\
(0.0077)\end{array}$ & Industry & $\begin{array}{c}-0.0036 \\
(0.0064)\end{array}$ & $\begin{array}{c}-0.0003 \\
(0.0056)\end{array}$ & $\begin{array}{c}-0.0055 \\
(0.0050)\end{array}$ & $\begin{array}{c}-0.0057 \\
(0.0100)\end{array}$ & $\begin{array}{l}-0.0090 \\
(0.0089)\end{array}$ \\
\hline Full Time & $\begin{array}{c}-0.0012 \\
(0.0033)\end{array}$ & $\begin{array}{l}-0.0015 \\
(0.0039)\end{array}$ & $\begin{array}{c}-0.0009 \\
(0.0057)\end{array}$ & $\begin{array}{c}0.0011 \\
(0.0093)\end{array}$ & $\begin{array}{c}-0.0034 \\
(0.0092)\end{array}$ & Manufacturing & $\begin{array}{c}0.0002 \\
(0.0026)\end{array}$ & $\begin{array}{c}-0.0078 \\
(0.0050)\end{array}$ & $\begin{array}{l}-0.0131 \\
(0.0053)\end{array}$ & $\begin{array}{c}-0.0124 \\
(0.0066)\end{array}$ & $\begin{array}{l}-0.0142 \\
(0.0075)\end{array}$ \\
\hline Full Time Equiv. & $\begin{array}{l}-0.0097 \\
(0.0029)\end{array}$ & $\begin{array}{l}-0.0110 \\
(0.0045)\end{array}$ & $\begin{array}{l}-0.0126 \\
(0.0050)\end{array}$ & $\begin{array}{l}-0.0118 \\
(0.0057)\end{array}$ & $\begin{array}{l}-0.0233 \\
(0.0094)\end{array}$ & No Targeting & $\begin{array}{c}0.0029 \\
(0.0028) \\
\end{array}$ & $\begin{array}{c}0.0015 \\
(0.0038) \\
\end{array}$ & $\begin{array}{c}-0.0002 \\
(0.0046) \\
\end{array}$ & $\begin{array}{l}-0.0012 \\
(0.0050)\end{array}$ & $\begin{array}{c}-0.0047 \\
(0.0052)\end{array}$ \\
\hline Part Time & $\ldots$ & $\ldots$ & $\ldots$ & $\begin{array}{c}0.0027 \\
(0.0023)\end{array}$ & $\begin{array}{c}0.0009 \\
(0.0039)\end{array}$ & Unemployed & $\begin{array}{c}0.0052 \\
(0.0022)\end{array}$ & $\begin{array}{c}0.0032 \\
(0.0024)\end{array}$ & $\begin{array}{c}0.0048 \\
(0.0047)\end{array}$ & $\begin{array}{c}0.0096 \\
(0.0064)\end{array}$ & $\begin{array}{c}0.0047 \\
(0.0077)\end{array}$ \\
\hline Not Specified & $\begin{array}{c}0.0047 \\
(0.0060) \\
\end{array}$ & $\begin{array}{c}0.0061 \\
(0.0041) \\
\end{array}$ & $\begin{array}{c}0.0030 \\
(0.0060) \\
\end{array}$ & $\begin{array}{c}0.0044 \\
(0.0058) \\
\end{array}$ & $\begin{array}{c}0.0085 \\
(0.0087) \\
\end{array}$ & Welfare recipient & .. & $\ldots$ & $\ldots$ & $\ldots$ & .. \\
\hline Equal to tax owed & $\begin{array}{c}-0.0059 \\
(0.0018)\end{array}$ & $\begin{array}{l}-0.0073 \\
(0.0039)\end{array}$ & $\begin{array}{l}-0.0110 \\
(0.0054)\end{array}$ & $\begin{array}{l}-0.0139 \\
(0.0065)\end{array}$ & $\begin{array}{l}-0.0269 \\
(0.0191)\end{array}$ & Disabled & $\begin{array}{l}-0.0137 \\
(0.0031)\end{array}$ & $\begin{array}{c}-0.0068 \\
(0.0029)\end{array}$ & $\begin{array}{l}-0.0012 \\
(0.0029)\end{array}$ & $\begin{array}{l}-0.0005 \\
(0.0037)\end{array}$ & $\begin{array}{c}-0.0045 \\
(0.0057)\end{array}$ \\
\hline Carry-forward & $\begin{array}{l}-0.0040 \\
(0.0083)\end{array}$ & $\begin{array}{l}-0.0103 \\
(0.0150)\end{array}$ & $\begin{array}{l}-0.0119 \\
(0.0136)\end{array}$ & $\begin{array}{l}-0.0109 \\
(0.0097)\end{array}$ & $\begin{array}{l}-0.0182 \\
(0.0169)\end{array}$ & No Targeting & $\begin{array}{c}0.0004 \\
(0.0029)\end{array}$ & $\begin{array}{c}0.0010 \\
(0.0054)\end{array}$ & $\begin{array}{l}-0.0028 \\
(0.0061)\end{array}$ & $\begin{array}{l}-0.0024 \\
(0.0073)\end{array}$ & $\begin{array}{l}-0.0051 \\
(0.0085)\end{array}$ \\
\hline Refundable & $\begin{array}{l}-0.0012 \\
(0.0032)\end{array}$ & $\begin{array}{l}-0.0013 \\
(0.0031)\end{array}$ & $\begin{array}{l}-0.0021 \\
(0.0040)\end{array}$ & $\begin{array}{c}-0.0004 \\
(0.0070)\end{array}$ & $\begin{array}{l}-0.0063 \\
(0.0050)\end{array}$ & Temporary & $\begin{array}{c}-0.0006 \\
(0.0032)\end{array}$ & $\begin{array}{c}-0.0024 \\
(0.0034)\end{array}$ & $\begin{array}{l}-0.0020 \\
(0.0052)\end{array}$ & $\begin{array}{l}-0.0021 \\
(0.0064)\end{array}$ & $\begin{array}{c}-0.0045 \\
(0.0104)\end{array}$ \\
\hline Not Specified & $\begin{array}{c}0.0045 \\
(0.0027)\end{array}$ & $\begin{array}{c}0.0007 \\
(0.0037)\end{array}$ & $\begin{array}{l}-0.0007 \\
(0.0048)\end{array}$ & $\begin{array}{l}-0.0004 \\
(0.0057)\end{array}$ & $\begin{array}{l}-0.0028 \\
(0.0068)\end{array}$ & Permanent & $\begin{array}{l}-0.0005 \\
(0.0024)\end{array}$ & $\begin{array}{l}-0.0006 \\
(0.0031)\end{array}$ & $\begin{array}{l}-0.0044 \\
(0.0032)\end{array}$ & $\begin{array}{l}-0.0038 \\
(0.0044)\end{array}$ & $\begin{array}{l}-0.0075 \\
(0.0049)\end{array}$ \\
\hline
\end{tabular}

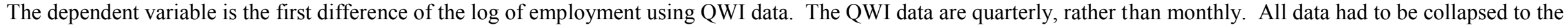

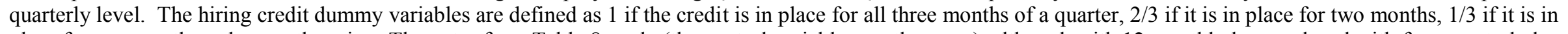

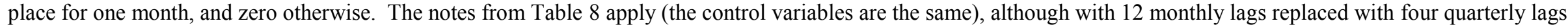

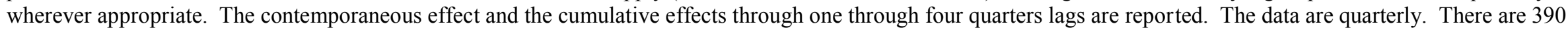

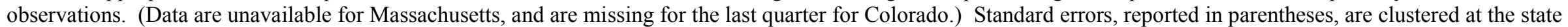
level. 
Table 13: Estimated Effects of State Hiring Credits on Hiring, Credit Dummy Variables Specifications, First Differences, 2007-2011, Quarterly Workforce Indicators Data

\begin{tabular}{|c|c|c|c|c|c|c|c|c|c|c|c|}
\hline Credit Variable(s) & Contemp. & +1 Lag & +2 Lags & +3 Lags & +4 Lags & Credit Variable(s) & Contemp. & +1 Lag & +2 Lags & +3 Lags & +4 Lags \\
\hline Credit & $\begin{array}{c}-0.0033 \\
(0.0250)\end{array}$ & $\begin{array}{c}-0.0557 \\
(0.0302)\end{array}$ & $\begin{array}{c}-0.0717 \\
(0.0617)\end{array}$ & $\begin{array}{c}-0.0834 \\
(0.0760)\end{array}$ & $\begin{array}{c}-0.0670 \\
(0.0837)\end{array}$ & Wage Requirement & $\begin{array}{c}0.0224 \\
(0.0214)\end{array}$ & $\begin{array}{c}0.0576 \\
(0.0322)\end{array}$ & $\begin{array}{c}0.0135 \\
(0.0309)\end{array}$ & $\begin{array}{c}-0.0108 \\
(0.0306)\end{array}$ & $\begin{array}{c}0.0268 \\
(0.0324)\end{array}$ \\
\hline Jobs & $\begin{array}{l}-0.0265 \\
(0.0447)\end{array}$ & $\begin{array}{l}-0.0935 \\
(0.0308)\end{array}$ & $\begin{array}{c}-0.1032 \\
(0.0527)\end{array}$ & $\begin{array}{c}-0.1272 \\
(0.0642)\end{array}$ & $\begin{array}{l}-0.1128 \\
(0.0700)\end{array}$ & No Wage Requirement & $\begin{array}{c}-0.0105 \\
(0.0269) \\
\end{array}$ & $\begin{array}{l}-0.0219 \\
(0.0319) \\
\end{array}$ & $\begin{array}{l}-0.0158 \\
(0.0397)\end{array}$ & $\begin{array}{c}-0.0522 \\
(0.0382)\end{array}$ & $\begin{array}{c}-0.0174 \\
(0.0562)\end{array}$ \\
\hline Payroll & $\begin{array}{c}0.0579 \\
(0.0404)\end{array}$ & $\begin{array}{c}0.0795 \\
(0.0307)\end{array}$ & $\begin{array}{c}0.0567 \\
(0.0425)\end{array}$ & $\begin{array}{c}0.0715 \\
(0.0608)\end{array}$ & $\begin{array}{c}0.0851 \\
(0.0680)\end{array}$ & Recapture & $\begin{array}{c}0.1357 \\
(0.0739)\end{array}$ & $\begin{array}{c}0.1236 \\
(0.0342)\end{array}$ & $\begin{array}{c}0.1095 \\
(0.0765)\end{array}$ & $\begin{array}{l}-0.0013 \\
(0.0348)\end{array}$ & $\begin{array}{c}0.1214 \\
(0.0557)\end{array}$ \\
\hline Investment & $\ldots$ & $\begin{array}{c}0.0593 \\
(0.0471)\end{array}$ & $\begin{array}{c}0.0784 \\
(0.0838)\end{array}$ & $\begin{array}{c}0.0303 \\
(0.0940)\end{array}$ & $\begin{array}{c}0.0638 \\
(0.0992)\end{array}$ & No Recapture & $\begin{array}{c}0.0086 \\
(0.0270) \\
\end{array}$ & $\begin{array}{c}-0.0307 \\
(0.0270) \\
\end{array}$ & $\begin{array}{c}-0.0253 \\
(0.0396) \\
\end{array}$ & $\begin{array}{c}-0.0249 \\
(0.0587) \\
\end{array}$ & $\begin{array}{c}-0.0432 \\
(0.0577) \\
\end{array}$ \\
\hline Others & $\begin{array}{c}0.0304 \\
(0.0419) \\
\end{array}$ & $\begin{array}{c}0.1092 \\
(0.0484)\end{array}$ & $\begin{array}{c}0.0472 \\
(0.0543) \\
\end{array}$ & $\begin{array}{c}0.0589 \\
(0.0304) \\
\end{array}$ & $\begin{array}{c}0.1367 \\
(0.0675) \\
\end{array}$ & Industry & $\begin{array}{c}-0.0117 \\
(0.0367)\end{array}$ & $\begin{array}{c}-0.0111 \\
(0.0483)\end{array}$ & $\begin{array}{c}-0.0358 \\
(0.0362)\end{array}$ & $\begin{array}{c}0.0078 \\
(0.0508)\end{array}$ & $\begin{array}{c}-0.0283 \\
(0.0564)\end{array}$ \\
\hline Full Time & $\begin{array}{c}0.0763 \\
(0.0660)\end{array}$ & $\begin{array}{c}0.0400 \\
(0.0624)\end{array}$ & $\begin{array}{c}0.0310 \\
(0.0743)\end{array}$ & $\begin{array}{l}-0.0226 \\
(0.0519)\end{array}$ & $\begin{array}{c}0.0329 \\
(0.0694)\end{array}$ & Manufacturing & $\begin{array}{l}-0.0179 \\
(0.0308)\end{array}$ & $\begin{array}{l}-0.0399 \\
(0.0410)\end{array}$ & $\begin{array}{c}0.0003 \\
(0.0337)\end{array}$ & $\begin{array}{c}-0.0254 \\
(0.0457)\end{array}$ & $\begin{array}{l}-0.0366 \\
(0.0534)\end{array}$ \\
\hline Full Time Equiv. & $\begin{array}{c}-0.0033 \\
(0.0300)\end{array}$ & $\begin{array}{c}0.0046 \\
(0.0293)\end{array}$ & $\begin{array}{c}-0.0081 \\
(0.0271)\end{array}$ & $\begin{array}{l}-0.0106 \\
(0.0360)\end{array}$ & $\begin{array}{c}0.0386 \\
(0.0495)\end{array}$ & No Targeting & $\begin{array}{c}0.0033 \\
(0.0241) \\
\end{array}$ & $\begin{array}{c}-0.0171 \\
(0.0383) \\
\end{array}$ & $\begin{array}{c}-0.0206 \\
(0.0529) \\
\end{array}$ & $\begin{array}{c}0.0040 \\
(0.0788) \\
\end{array}$ & $\begin{array}{c}-0.0065 \\
(0.0654) \\
\end{array}$ \\
\hline Part Time & $\ldots$ & $\cdots$ & $\ldots$ & $\begin{array}{l}-0.0252 \\
(0.0194)\end{array}$ & $\begin{array}{c}0.0184 \\
(0.0230)\end{array}$ & Unemployed & $\begin{array}{c}0.0921 \\
(0.0436)\end{array}$ & $\begin{array}{c}0.0896 \\
(0.0364)\end{array}$ & $\begin{array}{c}0.0785 \\
(0.0496)\end{array}$ & $\begin{array}{c}0.0876 \\
(0.0309)\end{array}$ & $\begin{array}{c}0.1154 \\
(0.0549)\end{array}$ \\
\hline Not Specified & $\begin{array}{l}-0.1307 \\
(0.0571)\end{array}$ & $\begin{array}{c}-0.0678 \\
(0.0698)\end{array}$ & $\begin{array}{l}-0.1104 \\
(0.0605)\end{array}$ & $\begin{array}{l}-0.1379 \\
(0.0710)\end{array}$ & $\begin{array}{l}-0.2290 \\
(0.0873)\end{array}$ & Welfare recipient & $\ldots$ & $\ldots$ & $\ldots$ & $\ldots$ & $\ldots$ \\
\hline Equal to tax owed & $\begin{array}{l}-0.0050 \\
(0.0290)\end{array}$ & $\begin{array}{l}-0.0352 \\
(0.0251)\end{array}$ & $\begin{array}{c}0.0014 \\
(0.0291)\end{array}$ & $\begin{array}{l}-0.0162 \\
(0.0431)\end{array}$ & $\begin{array}{c}0.0643 \\
(0.0453)\end{array}$ & Disabled & $\begin{array}{c}0.0828 \\
(0.0270)\end{array}$ & $\begin{array}{c}0.0279 \\
(0.0409)\end{array}$ & $\begin{array}{c}0.0569 \\
(0.0295)\end{array}$ & $\begin{array}{c}0.0586 \\
(0.0424)\end{array}$ & $\begin{array}{c}0.0926 \\
(0.0437)\end{array}$ \\
\hline Carry-forward & $\begin{array}{c}-0.0752 \\
(0.0279)\end{array}$ & $\begin{array}{c}0.0338 \\
(0.0317)\end{array}$ & $\begin{array}{c}-0.0012 \\
(0.0443)\end{array}$ & $\begin{array}{l}-0.0222 \\
(0.0655)\end{array}$ & $\begin{array}{c}0.0015 \\
(0.1105)\end{array}$ & No Targeting & $\begin{array}{c}-0.0018 \\
(0.0260) \\
\end{array}$ & $\begin{array}{c}-0.0559 \\
(0.0285) \\
\end{array}$ & $\begin{array}{c}-0.0752 \\
(0.0626) \\
\end{array}$ & $\begin{array}{c}-0.0883 \\
(0.0773) \\
\end{array}$ & $\begin{array}{c}-0.0617 \\
(0.0838) \\
\end{array}$ \\
\hline Refundable & $\begin{array}{c}0.0365 \\
(0.0286)\end{array}$ & $\begin{array}{c}0.0530 \\
(0.0458)\end{array}$ & $\begin{array}{l}-0.0006 \\
(0.0365)\end{array}$ & $\begin{array}{c}0.0288 \\
(0.0454)\end{array}$ & $\begin{array}{c}0.0710 \\
(0.0787)\end{array}$ & Temporary & $\begin{array}{c}0.0305 \\
(0.0325)\end{array}$ & $\begin{array}{c}0.0172 \\
(0.0292)\end{array}$ & $\begin{array}{c}0.0300 \\
(0.0336)\end{array}$ & $\begin{array}{c}-0.0054 \\
(0.0273)\end{array}$ & $\begin{array}{c}0.0259 \\
(0.0386)\end{array}$ \\
\hline Not Specified & $\begin{array}{c}0.0329 \\
(0.0283)\end{array}$ & $\begin{array}{l}-0.0498 \\
(0.0403)\end{array}$ & $\begin{array}{c}0.0146 \\
(0.0395)\end{array}$ & $\begin{array}{l}-0.0219 \\
(0.0315)\end{array}$ & $\begin{array}{l}-0.0103 \\
(0.0339)\end{array}$ & Permanent & $\begin{array}{c}-0.0103 \\
(0.0196)\end{array}$ & $\begin{array}{l}-0.0291 \\
(0.0277)\end{array}$ & $\begin{array}{l}-0.0303 \\
(0.0484)\end{array}$ & $\begin{array}{c}-0.0367 \\
(0.0590)\end{array}$ & $\begin{array}{l}-0.0185 \\
(0.0670)\end{array}$ \\
\hline
\end{tabular}

The dependent variable is the first difference of the log of hiring using QWI data. Notes from Table 12 apply. 
Appendix Table A1: Alabama Income Tax Capital Credit, Expenditure and Number of Jobs Created, as Reported by State

\begin{tabular}{|l|c|c|}
\hline Year & Actual credit expenditures & Jobs created \\
\hline 1995 & $\$ 0$ & 0 \\
\hline 1996 & $\$ 11,823$ & 417 \\
\hline 1997 & $\$ 2,399,482$ & 1394 \\
\hline 1998 & $\$ 1,416,479$ & 1980 \\
\hline 1999 & $\$ 1,315,505$ & 2867 \\
\hline 2000 & $\$ 2,877,828$ & 3748 \\
\hline 2001 & $\$ 6,284,852$ & 4855 \\
\hline 2002 & $\$ 14,030,156$ & 6331 \\
\hline 2003 & $\$ 20,423,672$ & 2008 \\
\hline 2004 & $\$ 45,025,240$ & 4286 \\
\hline 2005 & $\$ 34,324,981$ & 4517 \\
\hline 2006 & $\$ 41,631,715$ & 8665 \\
\hline 2007 & $\$ 124,443,097$ & 4778 \\
\hline 2008 & $\$ 63,249,598$ & 4647 \\
\hline 2009 & $\$ 47,599,172$ & 4757 \\
\hline 2010 & $\$ 49,685,106$ & 1169 \\
\hline 2011 & $\$ 43,882,657$ & 1011 \\
\hline 2012 & $\$ 55,620,850$ & 895 \\
\hline
\end{tabular}

Source: Alabama Department of Revenue, Annual Report, various years. Available at http://revenue.alabama.gov/anlrpt.cfm (viewed June 1, 2015). References: Alabama Department of Revenue, Annual Report, various years. Available at http://revenue.alabama.gov/anlrpt.cfm (viewed June 1, 2015). 